\title{
Emplacement of the Fogo Island Batholith, Newfoundland
}

\author{
K.L. CURrIE* \\ Geological Survey of Canada, 601 Booth Street, Ottawa, ON K1A 0E8 \\ * Correspondence address: 9 Tiverton Drive, Nepean, ON K2E 6L4
}

Date received:July 28, 2003 g Date accepted: October 11, 2003

\begin{abstract}
The Siluro-Devonian Fogo Island Batholith is a high-level, bimodal, sill-like unit about $7 \mathrm{~km}$ thick, intruded by a slightly younger, heterogeneous mafic unit. Stratigraphic evidence suggests emplacement of the batholith by raising of the roof without strong deformation of the host rocks. Large composite gabbro-microgranite dykes below the sill, intruded along axial planar cleavage, probably served as feeders. The upper $3-4 \mathrm{~km}$ of the sill comprise homogeneous to slightly zoned, coarse, hastingsite-biotite granite. Ignimbrite sheets of similar composition above the sill suggest that the granite was emplaced beneath cover rocks no more than $1 \mathrm{~km}$ thick. The lower $3 \mathrm{~km}$ of the sill consist of heterogeneous, locally layered, mafic rocks. Metre-scale, non-intrusive sheets of contrasting composition mark the contact between the granitic upper and mafic lower part of the sill. A late influx of mafic magma disrupted older mafic rocks and hybridised with granite, producing complex, heterogeneous "diorite". The local presence of A-type compositions in the granitic portion of the batholith may reflect diffusion during this process. A model for emplacement of the batholith assumes crustal anatexis above mantle-derived, underplated mafic magma, followed by passive emplacement of composite magma along tensional fractures related to movements on the Dog Bay Line, a dextral terrane boundary. Later movements on this feature controlled emplacement of further batches of magma, and finally tipped the batholith about $25^{\circ}$ to the north, producing its present configuration.
\end{abstract}

\section{RÉSUMÉ}

Le Batholithe siluro-dévonien de l'île Fogo forme une unité à l'aspect d'un filon-couche bimodale de niveau élevé et d'environ sept kilomètres d'épaisseur, dans laquelle fait intrusion une unité mafique hétérogène légèrement plus récente. Les observations stratigraphiques laissent supposer une mise en place du batholithe par soulèvement du toit sans déformation marquée des roches hôtes. Des dykes composites de gabbro-rhyolite de fortes dimensions au-dessous du filon-couche, ayant subi une intrusion le long de la schistosité de plan axial, ont probablement servi de voies de passage. Les trois à quatre kilomètres supérieurs du filon-couche sont constitués de granite à hastingsite-biotite grossier allant d'homogène à légèrement zoné. Des couches de tuf consolidé d'une composition semblable au-dessus du filon-couche permettent de supposer que la mise en place du granite s'est faite sous des roches de couverture d'au plus un kilomètre d'épaisseur. Les trois kilomètres inférieurs du filon-couche sont constitués de roches mafiques hétérogènes, localement stratifiées. Des nappes non intrusives de quelques mètres d'une composition différente marquent la zone de contact entre le sommet granitique et la base mafique du filon-couche. Un afflux tardif de magma mafique a perturbé les roches mafiques âgées et a entrainé une hybridation avec le granite, produisant des « diorites » hétérogènes complexes. La présence locale de compositions de type A dans la partie granitique du batholithe pourraient témoigner d'une diffusion au cours de ce processus. Un modèle de mise en place du batholite suppose une anatexie crustale au-dessus d'un magma mafique reposant sur des plaques et d'origine mantellique, suivie de la mise en place passive de magma composite le long de fractures de tension apparentées à des mouvements survenus le long de la ligne Dog Bay, une ligne de démarcation de terrane dextre. Des mouvements ultérieurs le long de cette ligne ont déterminé la mise en place d'autres mélanges de magma et ont finalement incliné le batholithe d'environ 25 degrés vers le nord, pour produire sa configuration existante.

[Traduit par la rédaction]

\section{INTRODUCTION}

Batholith emplacement, by definition, takes place deep within the crust under conditions which are difficult to determine precisely, and even more difficult to scale accurately in experiment or simulation, rendering dubious the applicability of conclusions reached from experimental and modelling stud- ies. Compare, for example, thermal modelling studies indicating that diapiric ascent of magma in the crust is impossible (Weinberg 1996; Petford 1996) with structural studies of felsic plutons indicating diapir-like emplacement (Sylvester 1964; Paterson and Vernon 1995). However, conditions of emplacement of a batholith can, in favourable cases, be constrained by stratigraphic, structural, and geochemical data. For the Fogo 


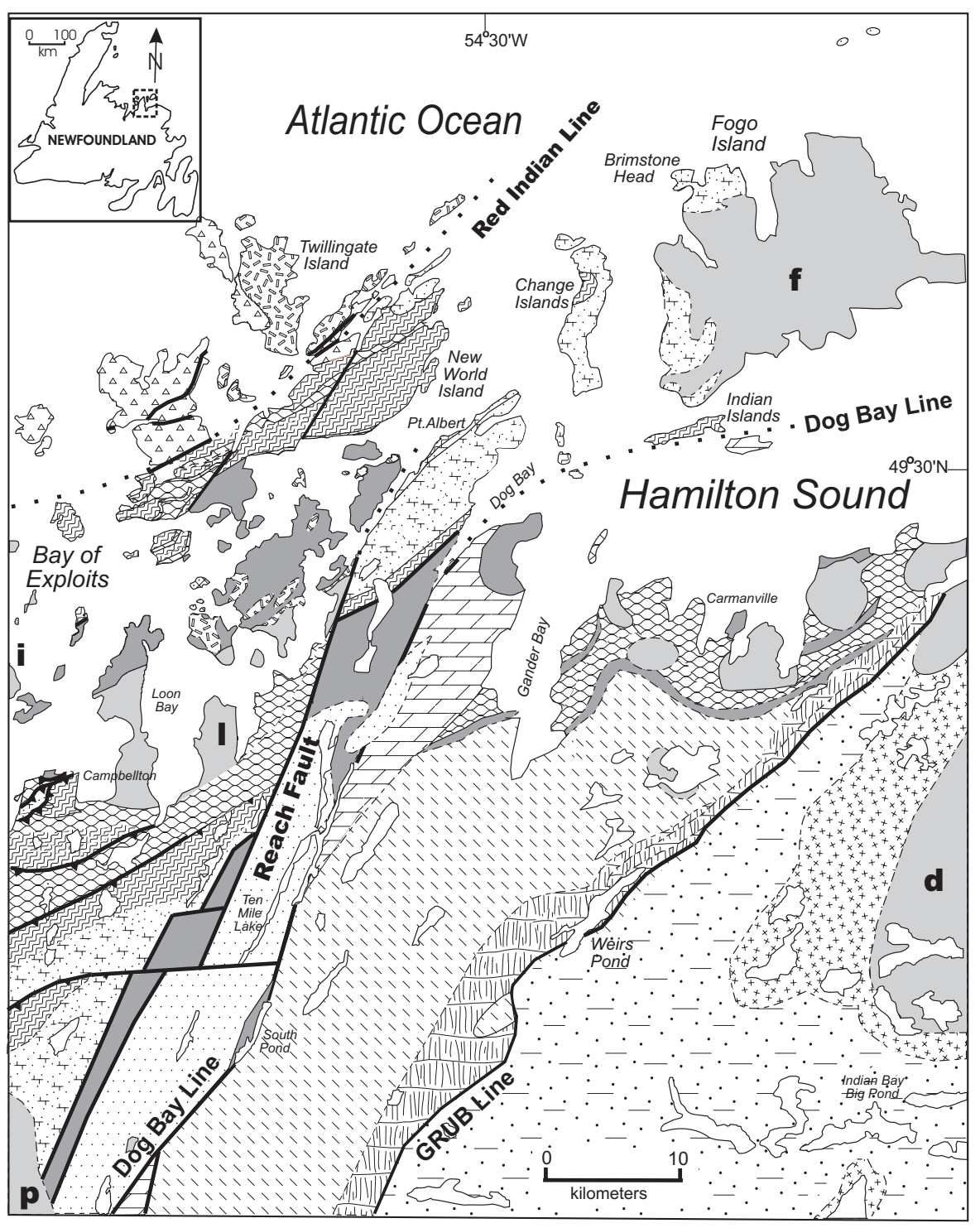

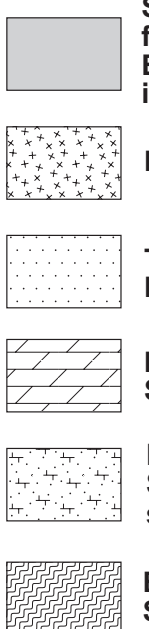

ro-Devonian batholiths; f-Fogo Island; d-Deadman's Bay; p-Mt.Peyton; I-Loon Bay i-Long Island

high-grade metamorphic rocks

Ten Mile Lake Formation; late Silurian redbeds

Indian Islands Group; Silurian siltstone and limestone

Botwood and Goldson groups; Silurian volcanic rocks, clastic sedimentary rocks, conglomerate

Badger Group; OrdovicianSilurian turbidite
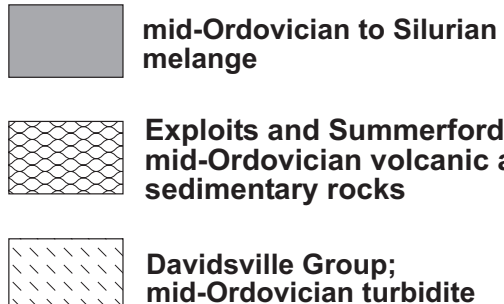

Exploits and Summerford groups; mid-Ordovician volcanic and sedimentary rocks

Davidsville Group; mid-Ordovician turbidite

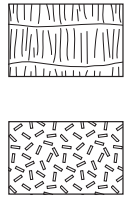

Gander River Complex; lower Ordovician ophiolite

lower Ordovician and older granitoid rocks

lower Ordovician and older oceanic and arc volcanic rocks

Gander Group; Cambrian psammite

Fig. 1 Regional geological setting of the Fogo Island Batholith (simplified after Currie 1995). The location of the map area is shown by the box on the inset map.

Island Batholith of northeast Newfoundland, these data provide valuable information on the evolution and emplacement of the batholith, including its geometric form and a mechanism of creating sufficient space for emplacement.

\section{GEOLOGICAL SETTING}

The Fogo Island Batholith lies within a curved, northeasttrending fault slice dominated by mid-Ordovician to Silurian strata (Fig.1) which underwent polyphase deformation in Silurian time (Karlstrom et al. 1982; Currie 1997c). Southwest of Fogo Island, isoclinal, steeply dipping, northeast-trending, northwest-verging structures dominate the outcrop pattern within this slice, but on Fogo Island these folds are open, with limb dips rarely exceeding $40^{\circ}$. The folded strata comprise back-arc volcanogenic rocks of the mid-Ordovician Exploits
Group (O’Brien et al. 1997), late Ordovician-early Silurian, westerly-derived, greywacke and conglomerate turbidites of the Late Ordovician-early Silurian Badger Group (Williams et al. 1995), and clastic and volcanic rocks of the Silurian Botwood Group (Williams 1972). The Dog Bay Line (Williams et al. 1993), a dextral terrane boundary marked by tectonic melange, juxtaposes the Badger and Botwood groups against Silurian limestone and limy coralline siltstone of the Indian Islands Group (Currie 1995). Along the Dog Bay Line, the bimodal Fogo Island Batholith abuts coeval peraluminous anatectic plutons (Currie and Pajari 1981) and the metaluminous early Devonian Deadman's Bay megacrystic pluton (D'Lemos and Holdsworth 1995). Metaluminous Siluro-Devonian bimodal batholiths similar to the Fogo Island Batholith occur between the Dog Bay and Red Indian lines (Mount Peyton, Loon Bay, Long Island), but northwest of the Red Indian Line only sparse Siluro-Devonian salic dykes occur (Elliot et al. 1991) 


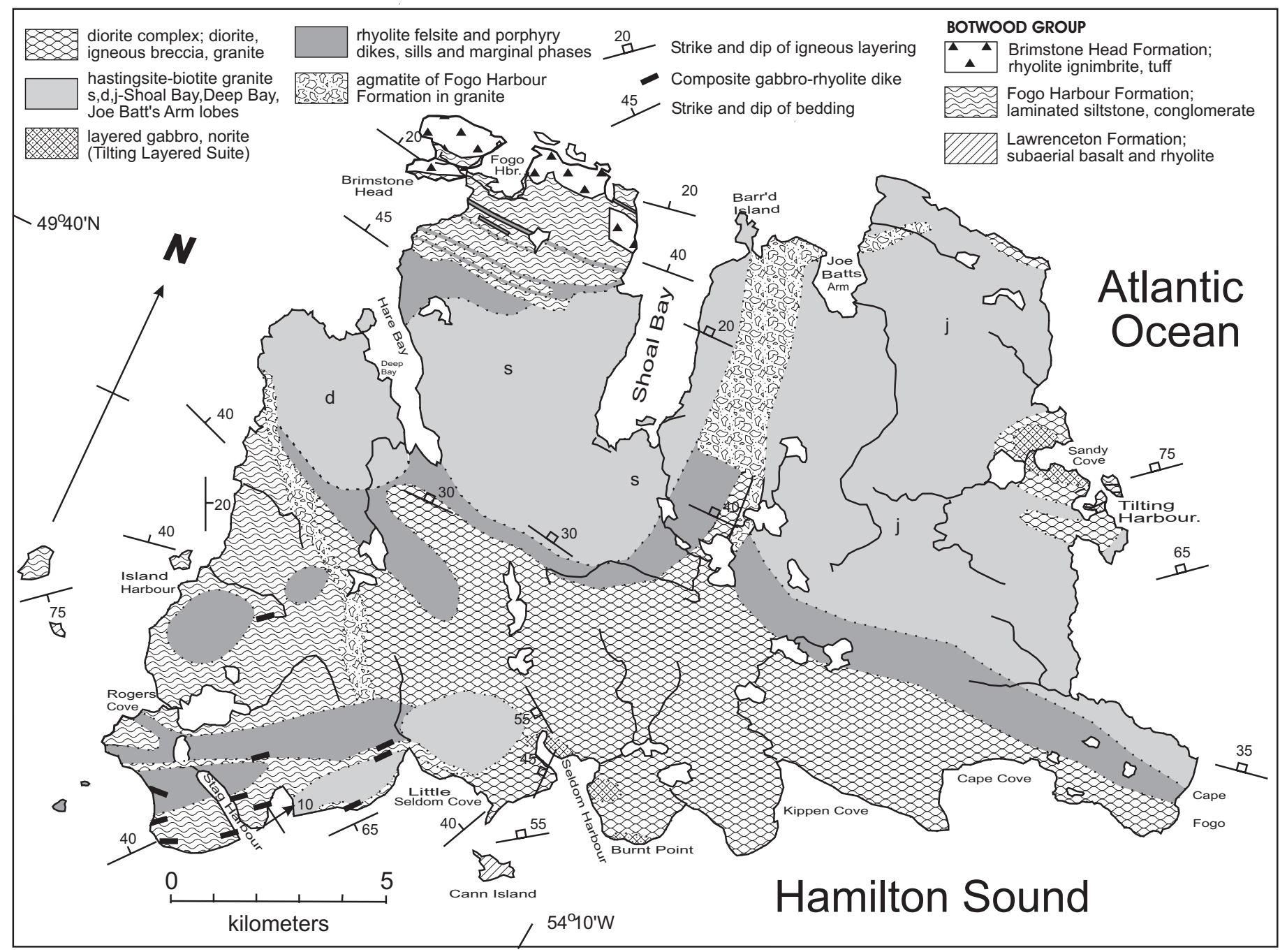

Fig. 2 Geological map of Fogo Island, Newfoundland (after Currie 1997b).

\section{DESCRIPTION OF UNITS}

\section{Botwood Group}

Fogo Island (Fig. 2) comprises salic and mafic igneous rocks of the Fogo Island Batholith and its host, the Botwood Group, which on Fogo Island comprises siltstone, sandstone, and matrix-supported conglomerate of the Fogo Harbour Formation overlain by rhyolite ignimbrite, rhyolitic tuff, and minor tuffaceous sandstone of the Brimstone Head Formation. The lowest unit of the Botwood Group, the Llandovery Lawrenceton Formation (Williams 1972), does not outcrop on Fogo Island, but appears on nearby islands. This formation, consisting of about equal amounts of basalt (flows and breccias) and rhyolite (flows, tuffs, and breccias), reaches thicknesses in excess of $2000 \mathrm{~m}$ on Change Islands, $10 \mathrm{~km}$ west of Fogo Island (Currie 1997a), but elsewhere does not exceed $300 \mathrm{~m}$ in thickness, suggesting presence of a vent area just west of Fogo Island. The presence of several rhyolite ignimbrite sheets within the Lawrenceton Formation indicates subaerial emplacement. The top $100 \mathrm{~m}$ of the Lawrenceton Formation contains metre-scale lenses of pale green, thinly laminated siltstone identical to the conformably overlying Fogo Harbour Formation.

The bulk of the Fogo Harbour Formation (Baird 1958) consists of grey-green to brown siltstone and sandstone, laminated on centimetre-scale, and exhibiting grading, ripple marks, and cross-bedding. Most exposures contain no obvious volcanic material, but a few beds contain 2 to $10 \%$ by volume of pink feldspar lapilli and crystal fragments up to a centimetre in diameter. Near Rogers Cove one bed contains volcanic bombs. Conglomerate lenses with rounded siltstone cobbles in a homogenised siltstone matrix occupy erosive channels up to $2 \mathrm{~m}$ thick. Composite stratigraphic sections for the Fogo Harbour Formation suggest a relatively constant thickness of 1000 to $1300 \mathrm{~m}$. Observations indicate a shallow marine origin for the formation, with the conglomerate intervals attributed to slumping during deposition. No fossils have been found in the Fogo Harbour Formation, but interbedding of its lower part with the Llandovery Lawrenceton Formation fixes a 
maximum age, and a precise $\mathrm{U}-\mathrm{Pb}$ zircon age of $422 \pm 2 \mathrm{Ma}$ (Ludlow) from a composite dyke cutting the formation on Dog Bay (Elliot et al. 1991) provides a minimum age.

A sharp, conformable contact of the Fogo Harbour Formation with the overlying Brimstone Head Formation (Baird 1958) can be traced across northern Fogo Island at the base of a cliff of rhyolite ignimbrite (Currie 1997b). A single metre-scale lens of tuffaceous sandstone resembling the underlying sedimentary section occurs about $60 \mathrm{~m}$ above the base of the Brimstone Head Formation at Brimstone Head. On Fogo Island, the Brimstone Head Formation comprises several sheets of densely welded, brown, rhyolite ignimbrite with a foliation marked by elongate pale streaks of less welded material (fiamme). Offshore islands consist of moderately welded crystal tuff and tuff breccia with a few lenses of red, subaerial sandstone up to $10 \mathrm{~m}$ thick. The thickness of the formation is unknown, but locally exceeds $1000 \mathrm{~m}$. The composition of the ignimbrite sheets resembles that of salic parts of the Fogo Island Batholith, and the Brimstone Head Formation may represent an erupted portion of the batholith, as suggested by Sandeman and Malpas (1995).

All of the supracrustal rocks on Fogo Island are openly folded about axial planes trending northeast and dipping about $65^{\circ}$ to the south. Limb dips rarely exceed $40^{\circ}$, and fold amplitudes vary from a few metres to a few hundred metres. All of the folds exhibit strong axial planar cleavage, a cleavage which is developed on a regional scale, extending tens of kilometres southwest from Fogo Island. An envelope to the folds dips north-northwest at about $25^{\circ}$, so that stratigraphically higher levels are exposed to the north.

\section{Fogo Island Batholith}

The Fogo Island Batholith, which underlies $80 \%$ of Fogo Island (about $250 \mathrm{~km}^{2}$ ) and also appears on small islands up to $8 \mathrm{~km}$ offshore to the east and southeast, intrudes the Fogo Harbour Formation. The batholith comprises five distinct lithologies. In order of decreasing age they are (1) agmatite containing blocks of host rock in a coarse-grained igneous matrix, (2) felsite, rhyolite porphyry, and microgranite, (3) layered and massive gabbro, (4) medium- to coarse-grained amphibolebiotite granite, (5) heterogeneous mafic rocks with a generally dioritic to tonalitic matrix containing schliers and blocks ranging from layered gabbro, to monzonitic, syenitic and granitic varieties. In the Tilting Harbour area, Aydin (1995) reported an emplacement age of $422 \pm 2 \mathrm{Ma}$ for the amphibole-biotite granite, and $408 \pm 2 \mathrm{Ma}$ for agmatitic diorite, consistent with field observations.

Layering in the batholith, commonly present in intermediate to mafic units and locally in granitic units, parallels bedding in nearby sedimentary rocks, and exhibits open folds congruent to those in the host rocks. However, folds in the igneous rocks do not exhibit axial planar cleavage, suggesting that folding in the host rocks pre-dated emplacement of the batholith, at least in part. Both top and bottom contacts of the batholith with the Fogo Harbour Formation can be observed in the western part of the island, dipping moderately north. These observations indicate a sill-like form for the exposed part of the batholith. Geological mapping shows the batholith to be about $6.5 \mathrm{~km}$ thick at its western end increasing to $8 \mathrm{~km}$ or more toward the east. The batholith comprises a homogeneous granitic upper part, 3-4 km thick, and a texturally complex intermediate to mafic lower part about $3 \mathrm{~km}$ thick.

Minor intrusive bodies related to the batholith occur both above and below the main mass. Dykes related to the batholith tend to strike parallel to bedding in the host rocks, but dip at high angles to bedding, lying in the axial planar cleavage of open folds. Below the body, on the southwest corner of the island, composite dykes up to $60 \mathrm{~m}$ thick (Fig.3) have a core of gabbro up to $20 \mathrm{~m}$ thick, commonly plagioclase-porphyritic, with thick rims of porphyry or microgranite chemically indistinguishable from granite of the main body. The contacts between mafic and salic phases are sharp, but lobate, with occasional rounded blobs or streaks of one lithology in the other, indicating some degree of mingling. These distinctive dykes occur up to $20 \mathrm{~km}$ from Fogo Island. One gave a precise $\mathrm{U}-\mathrm{Pb}$ zircon date of $422 \pm 2 \mathrm{Ma}$ (Elliot et al. 1991), identical to that of the main batholith. In some cases these dykes connect to small microgranite sills or laccoliths. Above the main body near Fogo Harbour, porphyry and microgranite dykes abound, but they lack mafic cores and rarely exceed $15 \mathrm{~m}$ in width. Many of these dykes connect to sills up to $10 \mathrm{~m}$ thick, with the dykesill transition forming prominent rock ridges, possibly due to thickening of the erosionally resistant igneous bodies at this point. Sandeman and Malpas (1995) considered these sills to be ignimbrite sheets, but their intrusive nature is demonstrated by (1) equal and intense hornfelsing of the host on both sides of the sills, and (2) presence of laminated siltstone on both sides with no increase in tuffaceous material.

\section{Agmatite}

Although some small-scale contacts of the batholith with its host rocks appear knife-sharp and generally conformable, agmatite (Fig. 4) commonly appears along internal and external contacts of the Fogo Island Batholith and may be up to $100 \mathrm{~m}$ thick. Agmatite in contact with the Fogo Harbour Formation consists of 50 to $80 \%$ of centimetre to metre-scale hornfelsed blocks of Fogo Harbour Formation in a medium- to coarse-grained matrix which is granitoid along the northern and southwestern margins of the complex, but becomes more tonalitic to the south. Similar agmatite forms a semi-continuous fringe, 10 to $100 \mathrm{~m}$ thick, separating granite bodies between Joe Batts Arm and Barr'd Islands. Within the agmatite, the blocks become larger and more coherent with distance from more massive igneous rocks, passing outward into irregularly folded sedimentary rocks with a few granite dykes. Throughout the agmatite, the blocks exhibit a strong preferred orientation, in many examples preserving only slightly disrupted stratigraphy. Within $50 \mathrm{~m}$ of the main body, some centimetre-scale beds appear to have melted to thin layers of brownish aphanitic material which locally forms a 


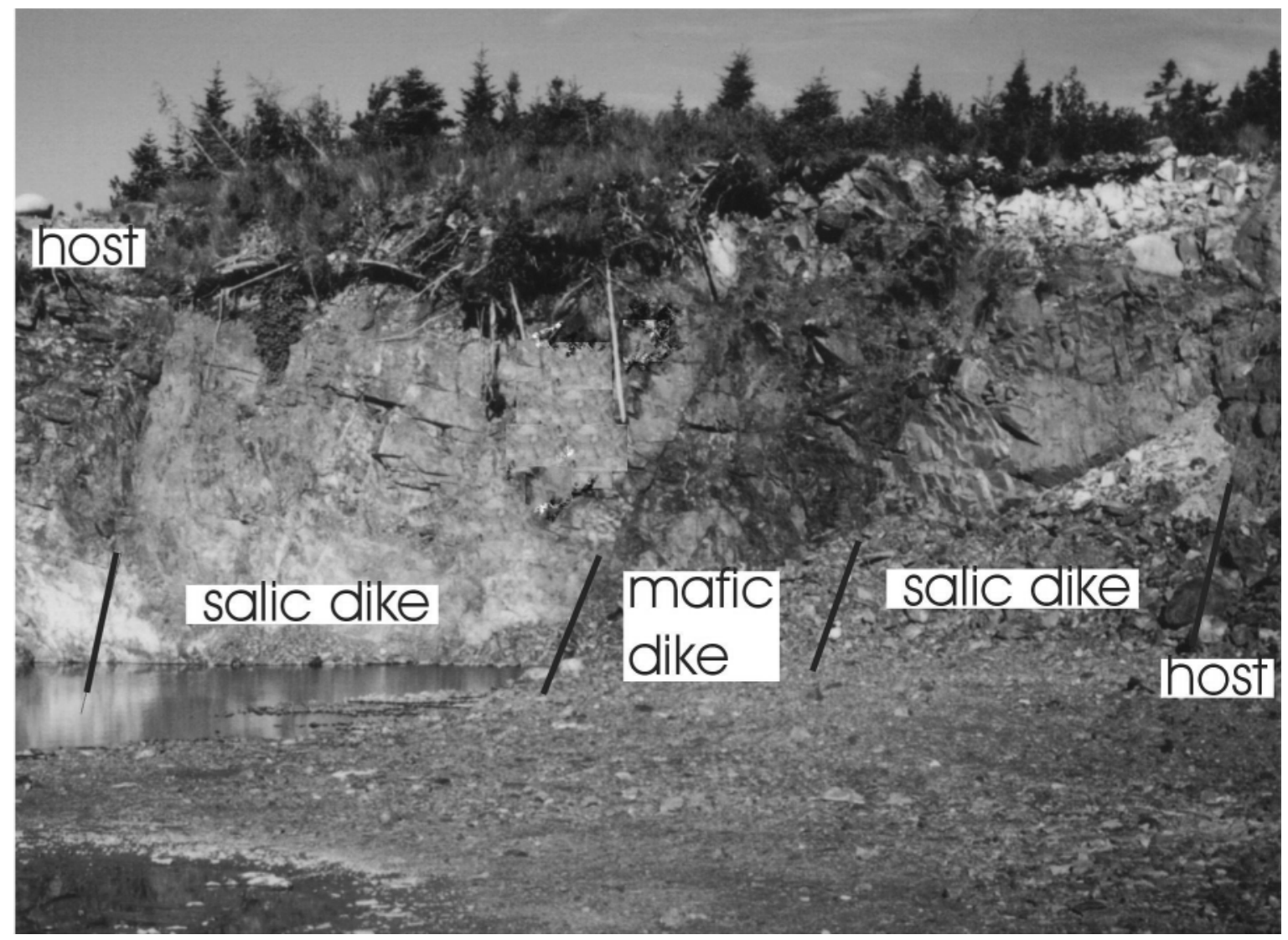

Fig. 3 Composite gabbro-rhyolite dyke, quarry west of Little Seldom Cove. The central mafic core of the dyke (dark grey) is $10 \mathrm{~m}$ wide with a grain size of 1-2 $\mathrm{mm}$. The microgranite rims, about $20 \mathrm{~m}$ wide, are aphanitic. Host rocks, siltstone of the Fogo Harbour Formation, visible to the left of the dyke, dip gently from left to right, perpendicular to the dip of the dyke. The height of the quarry face is about $10 \mathrm{~m}$. Note trees on top for scale.

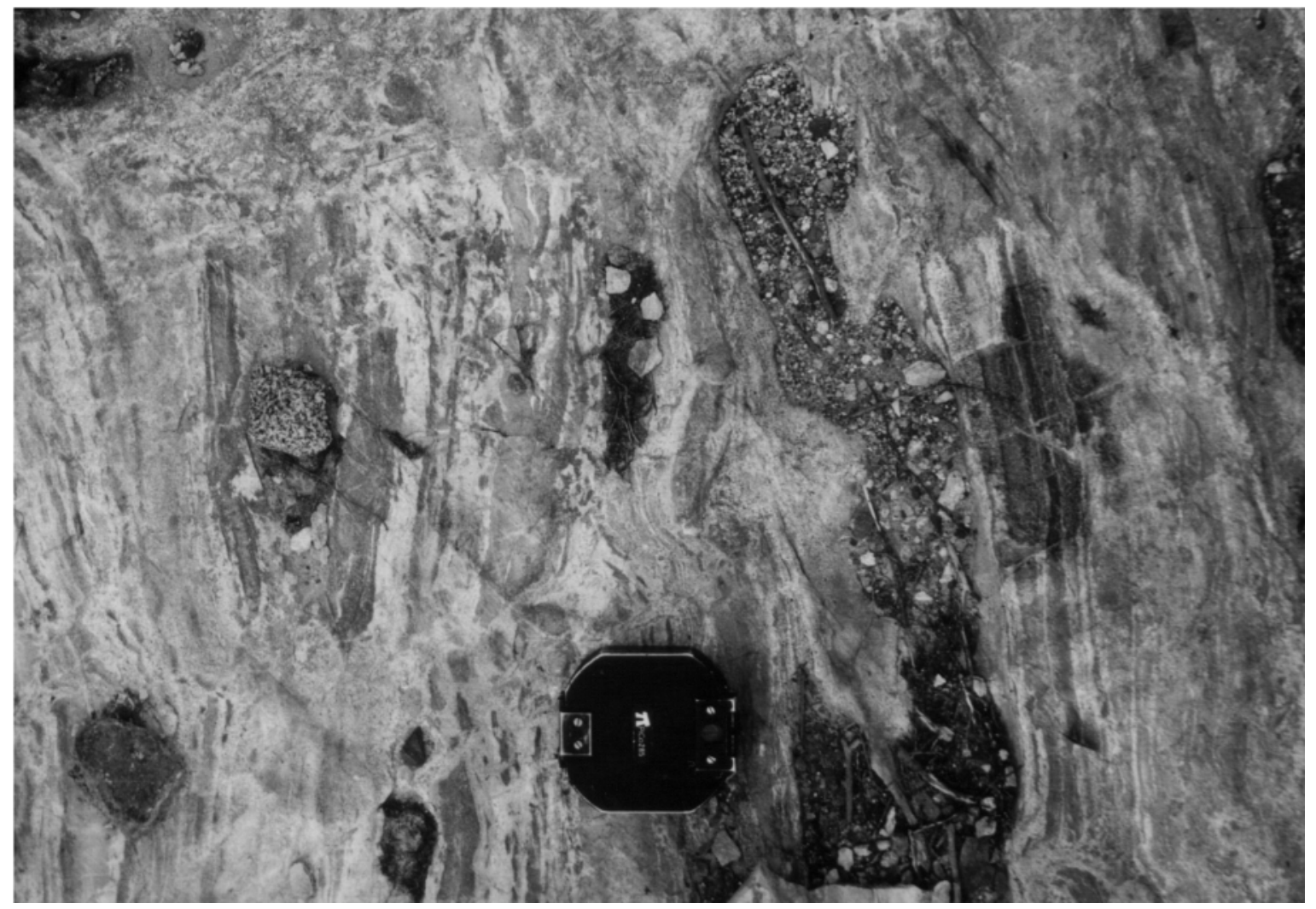

Fig. 4 Agmatite along the contact of the granite of the Fogo Island Batholith with the Fogo Harbour Formation, north of Island Harbour. Note the well-preserved foliation defined by disrupted beds. The pale grey material surrounding the lenticular fragments is felsite or granophyre, forming about $25 \%$ of the volume in this exposure. 
selvedge around blocks. Despite intense hornfelsing and possible local partial melting, new mineral growth was confined to sparse growth of fine biotite, suggesting that cooling took place rapidly enough that thermal equilibrium was never attained.

\section{Felsite, rhyolite porphyry, and microgranite}

The upper margin of the granite consists of an almost continuous layer of fine-grained, pink, felsic rock varying from featureless felsite to microgranite with abundant granophyric intergrowth and drusy miarolitic cavities, to rhyolite porphyry that is commonly spherulitic. Similar to identical lithologies occur as sills along the base of the granite where it contacts the mafic phase, and as sills and dykes above and below the batholith. In general felsite occurs close to the coarse-grained granite, whereas microgranite tends to form sills below the batholith, and rhyolite porphyry forms dykes above the batholith. However, there is no sharp division and all these rocks have similar or identical compositions (Appendix 1). A typical feature of all these rocks is presence of thin seams or clots of amphibole and magnetite. These segregations occur erratically in the felsic rocks (which otherwise contain virtually no mafic minerals) and also in hornfelsed country rocks adjacent to them.

Sandeman and Malpas (1995) reported that microgranite sheets cut the batholith, and that coarse-grained granite grades to microgranite. However, contacts between coarse and fine-grained to aphanitic felsic rocks are always sharp where exposed, and where intrusive relations can be determined, the coarse-grained phase invariably cuts the fine-grained one. Chemically no significant differences are present in major element composition between coarse-grained and fine-grained felsic rocks (Appendix 1). Sandeman and Malpas (1995) drew attention to enrichment of the fine-grained rocks in high-fieldstrength elements and $\mathrm{Ga} / \mathrm{Al}$ ratio, suggesting an A-type affinity. These tendencies are evident in all the felsic compositions (Fig. 5), and there appear to be no systematic differences in composition between fine-grained rocks and coarse-grained rocks, with the possible exception of slightly lower $\mathrm{FeO}^{*} / \mathrm{MgO}$ in the latter.

\section{Gabbro and basalt}

Baird (1958) noted the presence of layered mafic rocks around Tilting Harbour and Seldom Come By. The Tilting Layered Suite, which formed the subject of studies by Cawthorn (1978) and Aydin et al. (1994), underlies an oval area about 2 by $1.5 \mathrm{~km}$ in size, surrounded by hybrid dioritic rocks into which it grades, and by which it is intruded. Centimetre to metre-scale layering faces and dips $35-85^{\circ}$ to the north, and consistently pinches out to the southwest. Layers exhibit modal and textural variation, including repeated cycles from websterite bases (cumulate ortho- and clinopyroxene \pm olivine) to gabbro or leucogabbro tops (cumulate clinopyroxene and plagioclase). Large poikilitic hornblende and in some cases plagioclase overgrow the cumulates. Local convolute layering and prominent size and density sorting in some layers suggest deposition from magmatic currents, although much of the fine-scale layering may be due to in situ recrystallisation (Aydin et al. 1994). The top of the section, northwest of Tilting, consists of coarse-grained, unfoliated plagioclase-hornblende rocks which grade to quartz dioritic agmatite containing metrescale fragments of layered mafic rocks.

Gabbroic rocks around Seldom Come By form two ovoid masses. At Burnt Point, massive, pegmatitic gabbro contains cumulus ortho- and clinopyroxene, and large poikilitic postcumulus amphibole and plagioclase. The body contains about $10 \%$ of sinuous, boudinaged basalt dykes up to $50 \mathrm{~cm}$ wide. At the head of Seldom Harbour irregularly layered gabbro and diorite grade to heterogeneous mafic rocks which contain enclaves of layered gabbro, some sharply bounded in metrescale blocks, others apparently gradational to larger areas of massive gabbro.

The layered mafic rocks of the Fogo Island Batholith resemble large layered mafic intrusions, and imply that such a body was formed or disrupted during emplacement of the Fogo Island Batholith. Within the layered mafic rocks, abrupt reversals to a more primitive crystallisation order (clinopyroxene+plagioclase to orthopyroxene+olivine) imply repeated influx of primitive magma into a relatively stable magma chamber (Brown 1956; Wager and Brown 1968).

Gabbroic compositions commonly occur in dykes and sheets below the main batholith in the southwest corner of the island. Distinctive plagioclase-porphyritic gabbro, resembling the layered gabbro around Seldom Come By, occurs as discrete dykes, in the cores of composite dykes, as synplutonic dykes within the granite, and as synplutonic dykes within gabbro at Burnt Point.

Chemical analyses of non-cumulate gabbroic rocks from Tilting and Seldom show a considerable range of composition, ranging from subalkaline basalt across the andesite/basalt and andesite fields (Fig. 6d), a range approaching that of the apparently much more heterogeneous diorite complex (Appendix 1). On chemical discrimination diagrams (Fig. 6), compositions fall into both arc (Fig. 6a) and non-arc fields (Fig. 6b), with a large amount of scatter in some plots (Fig. 6c).

\section{Granite}

Coarse-grained granite of the Fogo Island Batholith occurs as an east-west belt across the northern part of the island, partially separated into three lobes by narrow belts of hornfelsed host rocks, agmatite, and sheets of felsite. All three lobes exhibit hastingsitic amphibole with minor biotite, and a colour index consistently $<15$. The central feldspar-porphyritic lobe contains 1 to $2 \%$ of digested mafic inclusions up to $5 \mathrm{~cm}$ across. The more equigranular eastern and western lobes lack mafic inclusions. All three lobes tend to be locally homogeneous, but become slightly more potassium feldspar-rich and leucocratic toward the north. All three lobes contain sinuous synplutonic basalt dyke segments exhibiting chilled margins, commonly 1 to $2 \mathrm{~m}$ wide and 5 to $10 \mathrm{~m}$ long (Fig. 7). Dyke lithologies 
(a)

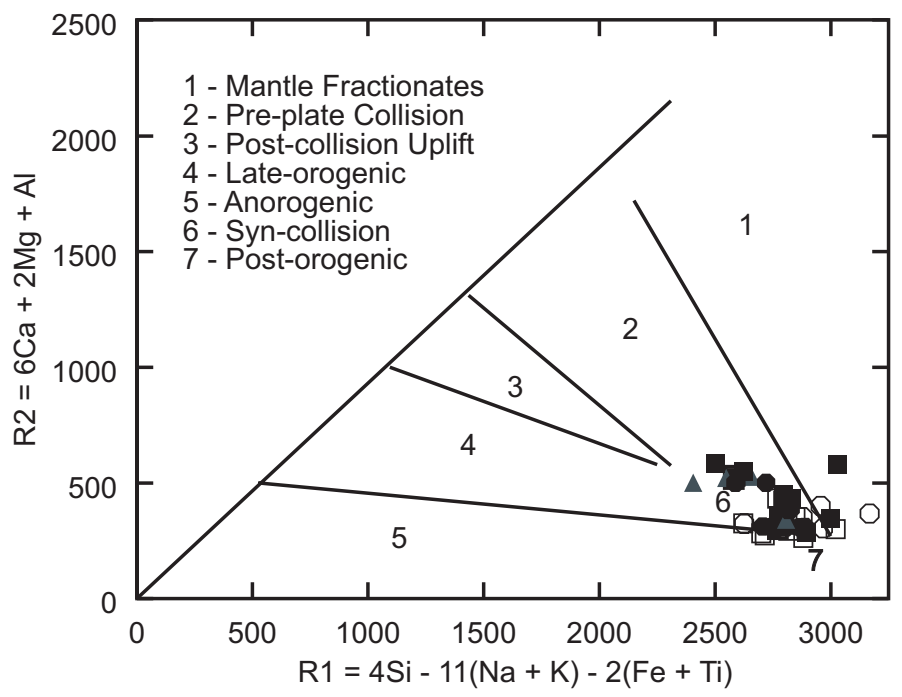

(c)

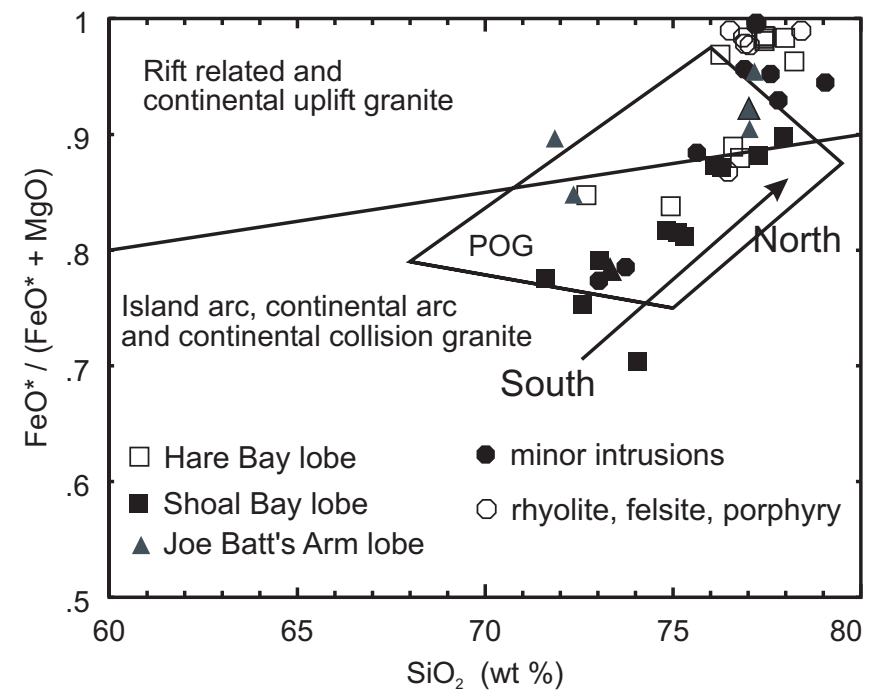

(b)

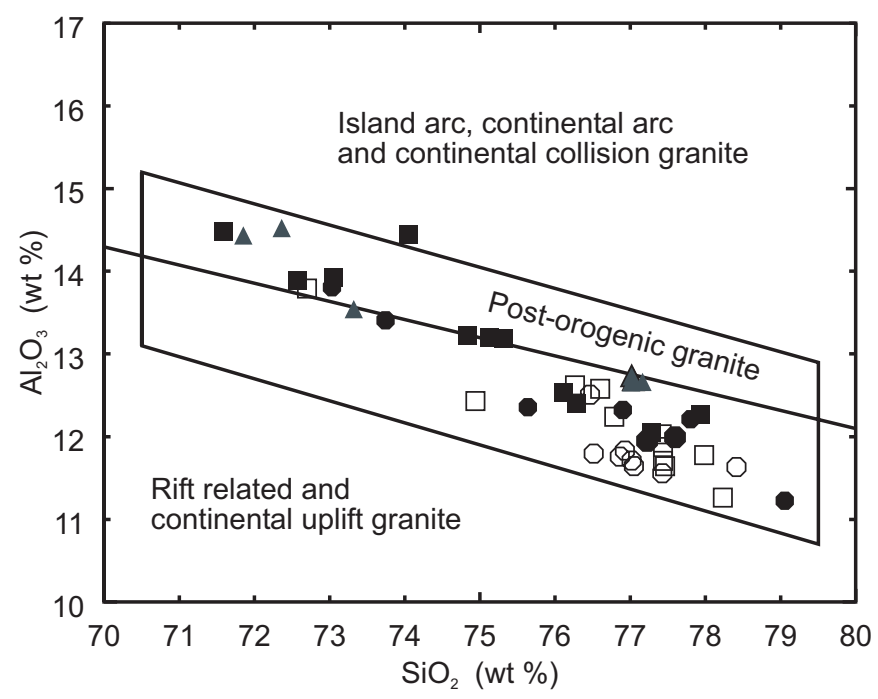

(d)

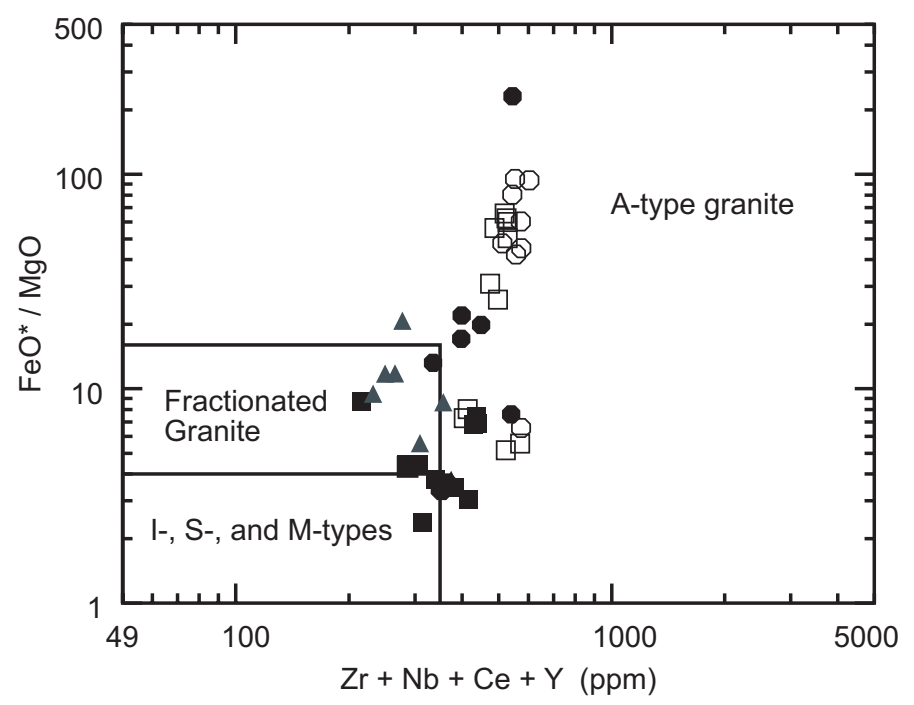

Fig. 5 Chemical data for salic rocks of the Fogo Island Batholith plotted on tectonic discrimination diagrams of (a) Batchelor and Bowden (1985), (b and c) Maniar and Piccoli (1989), and (d) Whalen et al. (1987).

include plagioclase-porphyritic varieties similar to the cores of composite gabbro-rhyolite dykes. Felsic dykes and pegmatite are absent and quartz veins extremely rare (one observed).

South of Fogo Harbour, granite cuts across a carapace of felsite and rhyolite sills, and is in essentially conformable contact with strongly hornfelsed sedimentary rocks. This region exhibits crude sheeting parallel to the contact, and prominent joints perpendicular to the contact.

Chemically, all analyses of the granite fall in a restricted field (Fig. 5). On the diagram of Batchelor and Bowden (1985) this region straddles the boundary between late orogenic and postorogenic granites (Fig. 5a), whereas in the diagrams of Maniar and Piccoli (1989), it clearly falls in the post-orogenic granite field (Fig. 5b, c). The trend to more differentiated compositions from south to north in all lobes can be seen in Fig. $5 \mathrm{c}$ (increasing $\mathrm{SiO}_{2}$ and $\left.\mathrm{FeO}^{*} /\left(\mathrm{FeO}^{*}+\mathrm{MgO}\right)\right)$ The tendency toward A-type compositions noted by Sandeman and Malpas (1995), seen in Fig. 5 d, results from relatively high contents of $(\mathrm{Zr}+\mathrm{Nb}+\mathrm{Ce}+\mathrm{Y})$ combined with extreme depletion in $\mathrm{MgO}$ (producing extreme $\mathrm{FeO}^{*} / \mathrm{MgO}$ ratios). Alkali contents are not unusually high.

\section{Diorite complex}

The diorite complex forms the largest and most complex unit of the Fogo Island Batholith. Some dioritic rocks exhibit coarse, massive textures comparable to those of the gabbro and granite. However, large exposures invariably include patchy, inequigranular textures, streaks of one lithology in another, and schlieren and blocks of more mafic lithologies in a dioritic to granitic matrix. Characteristic gradational, centimetre-scale pegmatitic patches with large amphibole and feldspar crystals have widely varying alkali feldspar/plagioclase ratios, and 
(a)

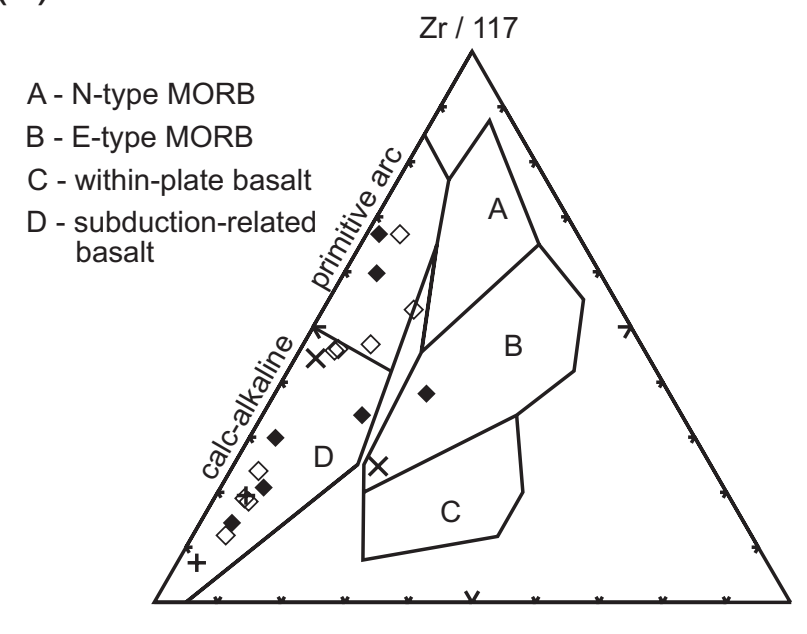

Th (b)

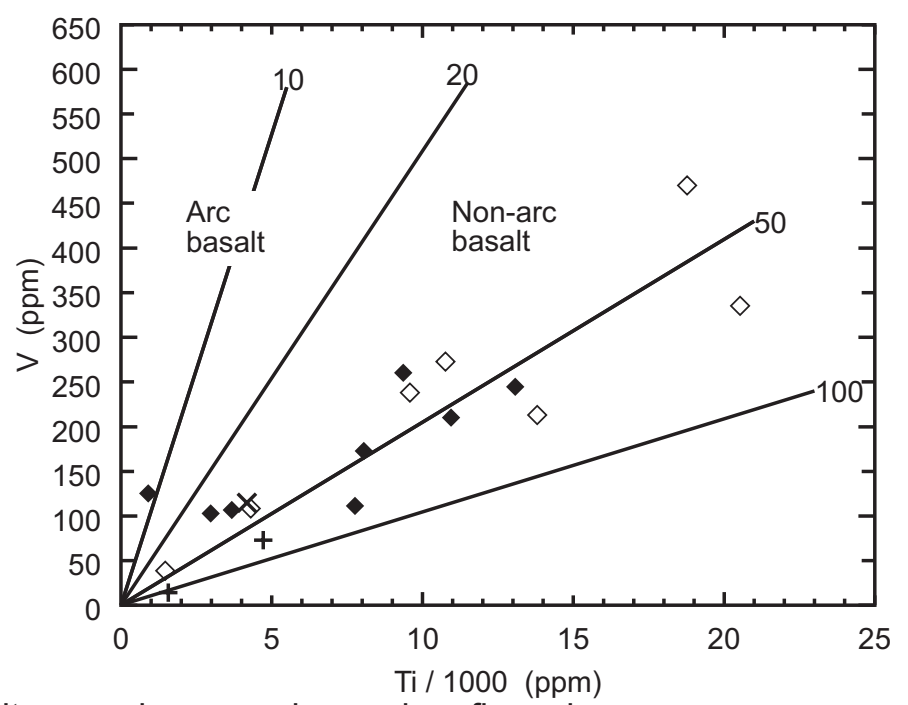

diorite complex $\diamond$ layered mafic rocks

(d) (c)

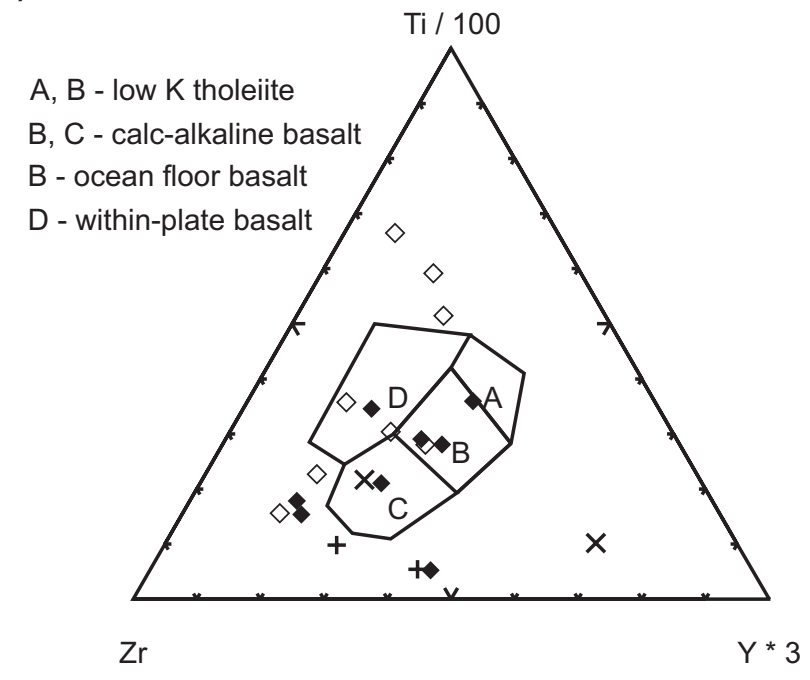

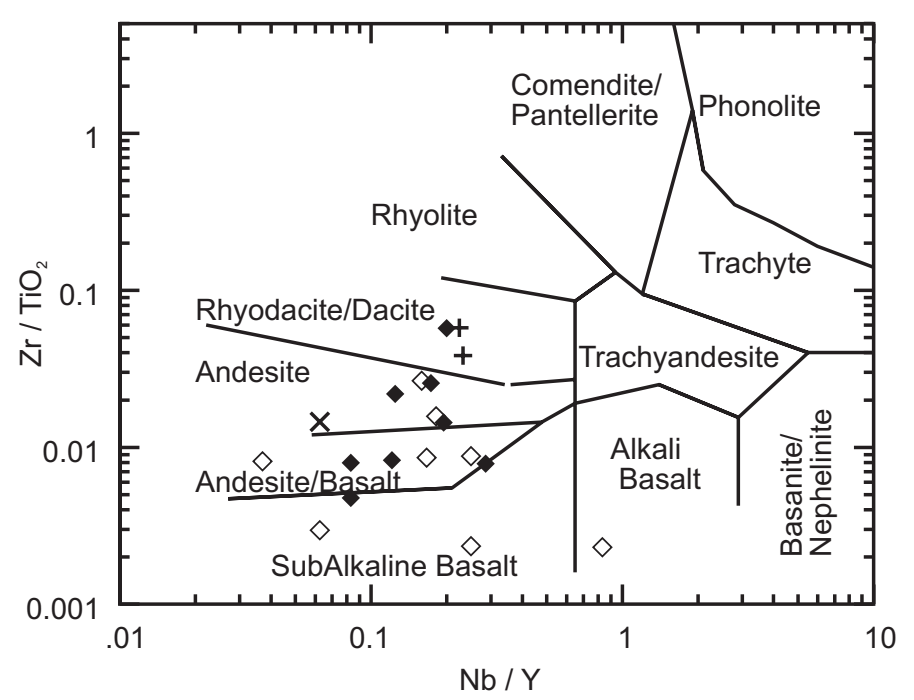

Fig. 6 Chemical data for mafic rocks of the Fogo Island Batholith plotted on tectonic discrimination diagrams of (a) Wood (1980), (b) Shervais (1982), (c) Pearce and Cann (1973), and (d) Winchester and Floyd (1977).

may contain a significant amount of quartz. Igneous breccias of diverse mafic blocks in a more salic matrix form a major part of the diorite complex (Fig. 8). The mafic component varies from rare examples of layered gabbro, to hornblenderich amphibolite to hornblende-plagioclase rocks with minor quartz. In coastal exposures at Wild Cove, Cape Fogo, and Kippen Cove some mafic blocks exhibit intimate, amoeboid interfingering with the matrix, and form pillow-like masses, phenomena suggestive of coexisting magmas. The composition of the more homogeneous parts of the diorite complex ranges from gabbroic through hornblende diorite and quartz diorite to tonalite, monzodiorite, and rare syenite. Mafic varieties contain mafic inclusions, whereas more silicic varieties contain more silicic inclusions. Much of the interior part of the diorite complex comprises locally homogeneous, fine to medium-grained, granoblastic hornblende-plagioclase rocks with variable but minor amounts of clinopyroxene, quartz, and potash feldspar. Many of these rocks exhibit nebulous pegmatitic patches of hornblende+plagioclase, commonly associated with healed, epidote-filled fractures.

Near the contact between the diorite complex and granite, diorite and granite are typically observed in alternate outcrops, or in small adjacent areas with few exposed contact relations. In a large highway quarry, felsite and diorite form conformable, non-intrusive, metre-scale sheets. Coastal exposures at Cape Fogo and Cape Cove exhibit a variety of complex relations ranging from complexes of sills with contrasting compositions, through diorite cross-cut by granite, or pillows of mafic in salic 


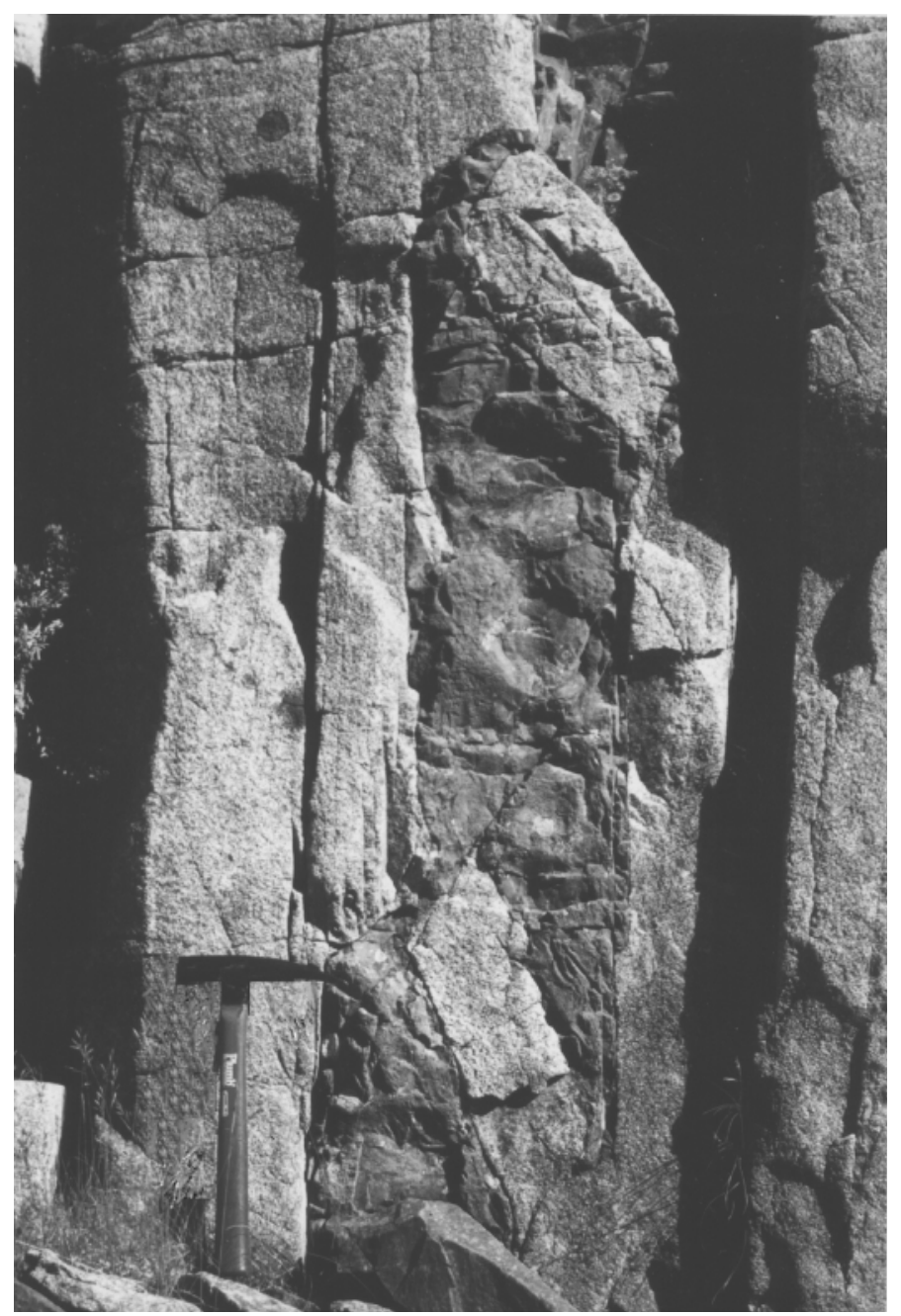

Fig. 7 Synplutonic mafic dyke segment in granite, Deep Bay. The hammer at lower left is $30 \mathrm{~cm}$ long.

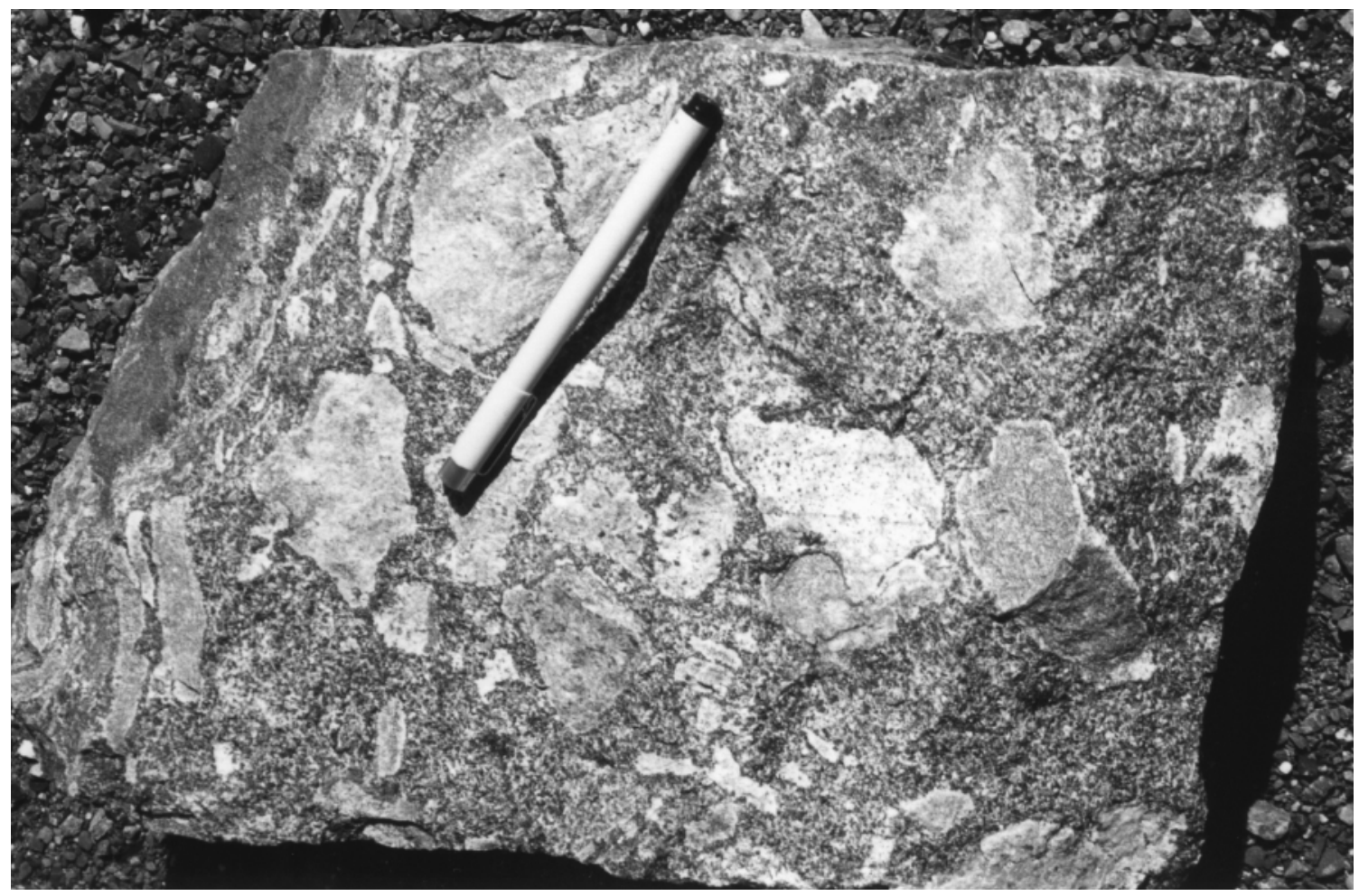

Fig. 8 Agmatite with diorite and leucogabbro blocks in a dioritic matrix, Seldom Come By. The two elongate blocks in the lower left corner are Fogo Harbour Formation. Note the pale-coloured reaction rims on some specimens. The pen is $13 \mathrm{~cm}$ long. 
phases, to completely gradational contacts over a few tens of centimetres. In the absence of definitive contact relations, Baird (1958) and Sandeman and Malpas (1995) interpreted the salic phases of the batholith to intrude the mafic phases. However, field observations during the present study generally suggested originally non-intrusive contacts within a zone of mingling.

Although the textural range of the diorite complex is bewilderingly large, chemical analyses (Appendix 1) show a limited range of composition, with $\mathrm{SiO}_{2}$ content ranging fairly continuously from 52 to $61 \%$. Two samples yielded $\mathrm{SiO}_{2}$ contents of 64 and $75 \%$. The former is the only one of 65 analyses of the batholith with an $\mathrm{SiO}_{2}$ content between 61 and $70 \%$. In general, analyses of the diorite complex plot in the same fields as the layered mafic rocks (Fig. 8) but contain much higher concentrations of $\mathrm{K}, \mathrm{Zr}$, and $\mathrm{U}$, and lower contents of $\mathrm{Mg}$. An obvious possible cause for these anomalies could be mixing with the granitic component of the batholith, as suggested by field observations. The strongly bimodal nature of the analyses shows that if this model is correct, mixing involved incorporation of the salic component into the mafic phase but little incorporation of the mafic component into the salic phase.

\section{A MODEL FOR EMPLACEMENT OF THE FOGO ISLAND BATHOLITH}

The Fogo Island Batholith consists of a homogeneous salic portion and a texturally heterogeneous mafic portion which includes layered rocks. A model for emplacement must explain the presence and mutual relations of these components. Field observations relevant to emplacement of the batholith may be summarised as follows. (1) Most mafic dyke emplacement and all salic dyke emplacement preceded emplacement of the main batholith and followed a near-vertical cleavage axial planar to pre-batholith open folds. (2) Composite dykes with mafic cores occur below the batholith but not above it. (3) The older part of the batholith, a thick sill, is gravitationally stratified, with mafic rocks at the base and salic rocks at the top. (4) Layered mafic rocks are disrupted by and included within heterogeneous mafic to intermediate rocks which show evidence of magma mixing and assimilation. (5) The bimodal Fogo Island Batholith developed close to a vent area of slightly older bimodal volcanic rocks of the Lawrenceton Formation.

These observations suggest a three-stage model for emplacement, namely (i) generation of a composite magma, here assumed to be due to mafic underplating of the crust with subsequent crustal anatexis, (ii) buoyant rise of the composite magma followed by gravitational differentiation to produce the sill-like mass, and (iii) a late influx of mafic magma. These stages are cartooned in Fig. 9, which uses the time scale of Tucker et al. (1990) for comparison of stratigraphic and absolute ages.

Eruption of the bimodal, subduction-related (Currie 1995) Lawrenceton Formation (Fig. 9a) had almost ceased by Late Llandovery time ( $430 \mathrm{Ma}$ ) as motion along the Dog Bay Line passed from subduction to dextral transpression (Karlstrom et al. 1982). Reduction of magmatic activity led to subsidence due to cooling of the crust, permitting a marine incursion and deposition of the Fogo Harbour Formation. Magmatism had not completely ceased, as shown by presence of tuffaceous material in the Fogo Harbour Formation. The model assumes that mafic magma, no longer able to erupt, underplated the crust where dextral transpression was converted into extension at the bend in the Dog Bay Line (Fig. 9b). The need for such a deep-seated precursor to the high-level Fogo Island Batholith follows from the regional distribution of the composite dykes which appear to have fed the batholith.

Large scale emplacement of mafic magma eventually caused anatexis of surrounding crustal host rocks, initially producing a gravitationally stable system with light salic magma above dense mafic magma. Such a system is unstable relative to its host because both components have positive buoyancy with respect to continental crust (Glazner 1994). If the volume of magma becomes sufficiently large, it will rise buoyantly along fractures. Analogs of basalt-rhyolite systems experimentally studied by Huppert and Sparks (1988) showed that fingers of hot mafic rock rise through the overlying salic melt carrying salic material along with them. The composite dykes below the Fogo Island Batholith suggest such a process, with magma following cleavage axial planar to slightly earlier folds (Fig. 9c). The large size of the dykes, and lack of mixing of salic and mafic components, suggest that these fractures may have opened during emplacement, allowing passive emplacement with the mafic magma rising to its neutral buoyancy level, and spreading laterally.

Glazner (1994) estimated the density of mafic magma near surface to be about $2.75 \mathrm{~g} / \mathrm{cm}^{3}$, in reasonable accord with the measurement of $2.73 \mathrm{~g} / \mathrm{cm}^{3}$ for erupting Kilauea basalt

Fig. 9 (Facing page) Cartoon of a model for the emplacement of the Fogo Island Batholith. (a) 430 Ma; Emplacement of the bimodal Lawrenceton Formation above a subduction zone. (b) 430-422 Ma; Mafic underplating of continental crust as the effusive outlets are cut off by conversion of subduction into dextral transcurrent motion. Anatectic melt forms at the base of the crust due to the influx of heat. (c) $422 \mathrm{Ma}$; Buoyant rise of composite magma rising as dykes along axial plane cleavage to the level of neutral buoyancy. The roof is assumed to float upward, creating space. Part of the light salic fraction forms sills of felsite and porphyry, eventually reaching the surface as ignimbrites, while the mafic fraction sinks to the base. Stable conditions permit gravitational differentiation and widespread formation of igneous layering. (d) $408 \mathrm{Ma}$; A late influx of mafic magma into the body disrupts the mafic portion, producing widespread agmatisation and hybridisation. The mafic magma remains below the salic rocks due to its higher density, but the high temperature and composition contrast produce double diffusive exchange across the boundary, creating local A-type granite in the salic rocks. 

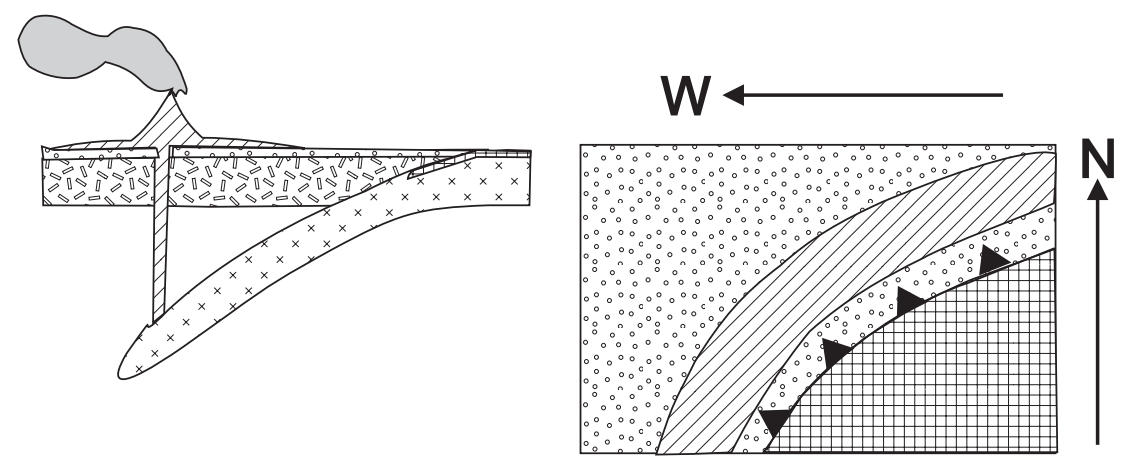

(a) 430 Ma; eruption of Lawrenceton Formation
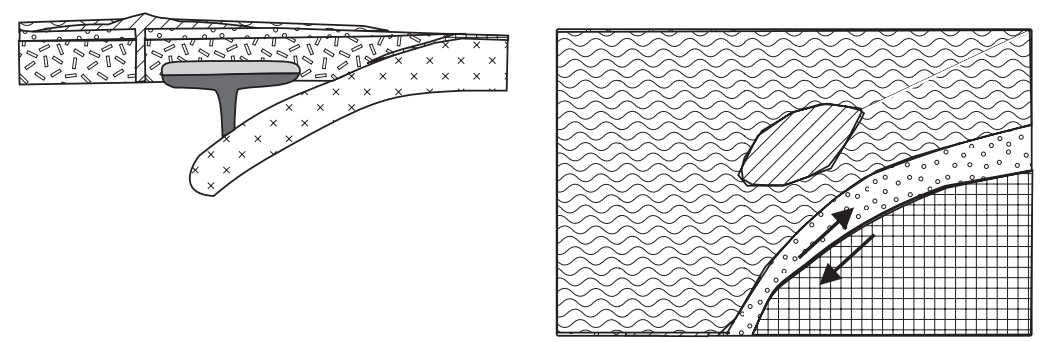

(b) 430-422 Ma;

mafic underplating, anatexis, surficial subsidence and deposition due to cooling
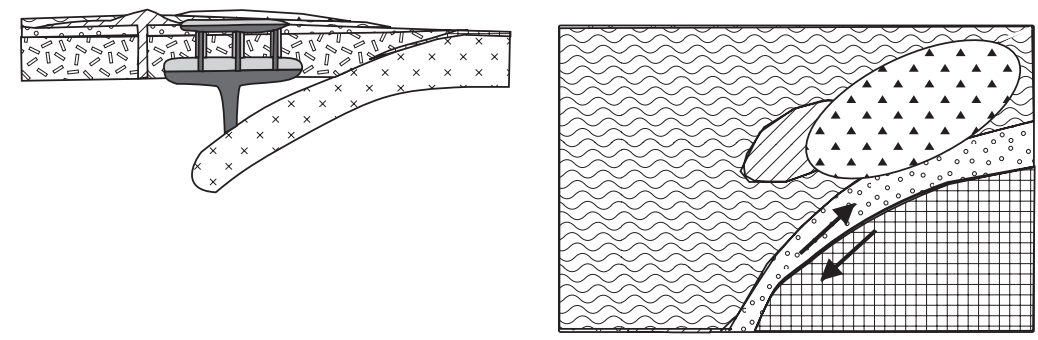

(c) $422 \mathrm{Ma}$;

rise, spread and differentiation of composite magma, ignimbrite sheets erupted on floating roof
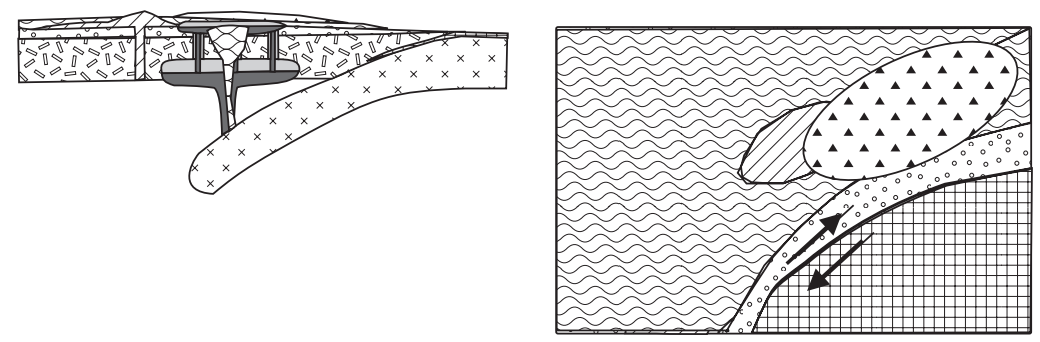

(d) $408 \mathrm{Ma}$;

emplacement of late mafic rocks, disrupting and hybridizing with earlier phases, formation of "diorite"

$\therefore \quad$ Brimstone Head Formation;

rhyolite ignimbrite

late mafic rocks

(diorite complex)

Fogo Harbour Formation;

siltstone and tuff

granite. felsite, rhyolite

Lawrenceton Formation;

bimodal volcanic rocks

Indian Islands Group;

limey siltstone, limestone

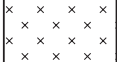

early mafic rocks,

commonly layered

oceanic crust

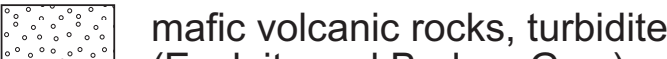

(Exploits and Badger Gps.)

continental crust 
(Macdonald 1963). Both values are higher than the density of Fogo Harbour Formation $\left(2.68 \mathrm{~g} / \mathrm{cm}^{3}\right)$ but lower than the density of basalt of the Lawrenceton Formation $\left(\sim 2.89 \mathrm{~g} / \mathrm{cm}^{3}\right)$. Currie (1995) found the latter to be underlain by a thick section of Ordovician mafic volcanic rocks and a thin section of Ordovician-Silurian greywacke (Badger Group). It is therefore plausible that mafic magma would rise buoyantly to the top of the mafic volcanic rocks, but stop near the base of the lowdensity Fogo Harbour Formation. The abrupt transition from submarine deposition of the Fogo Harbour Formation to the subaerial ignimbrite sheets of the Brimstone Head Formation required rapid uplift which could be explained by floating of the Fogo Harbour Formation on underlying magma, combined with thermal expansion.

The thick composite dykes intruding the Fogo Harbour Formation strongly suggest that the magma was composite when emplaced. Gravitational differentiation of such composite magma would lead to formation of salic upper and mafic lower parts. Because the density of the salic portion would be less than that of the host Fogo Harbour Formation, it could continue to rise, hypothetically producing the three observed domes and their dividing screens of agmatite. Given sufficient heat content and appropriate channels, it could eventually reach the surface and erupt to form ignimbrite sheets (Brimstone Head Formation).

The proposed model requires passive conditions of emplacement. Layered mafic rocks, the presence of composite dykes, and apparent large-scale gravitational differentiation of composite magma all indicate stable conditions. Repetition of cumulus assemblages (olivine +orthopyroxene) in the layered gabbro suggests that minor influxes of fresh mafic magma did not disturb these conditions. However, influx of a large volume of mafic magma (Fig. 9d) would upset the delicate thermal steady state producing vigorous convection and hybridisation with slightly older, still hot, phases of the batholith. Along contacts with salic rocks, remelting could form some salic liquid, leading to the formation of complex salic-mafic relations, including pillow-like masses of mafic rocks in salic matrices, and some cross-cutting of mafic rocks by salic dykes. Conditions along such interfaces would favour extensive double diffusive transfer of material across the boundary, leading to A-type tendencies in the overlying granite according to the model of Wiebe (1994).

The present superb exposure of internal structure of the Fogo Island Batholith results from tipping of the batholith at a moderate angle to the northwest subsequent to emplacement by minor late sinistral movement on the Dog Bay Line (Williams et al. 1993; Piasecki 1992) which produced compression in the Fogo Island region in early to mid-Devonian time.

\section{ACKNOWLEDGEMENTS}

This is Geological Survey of Canada Contribution Number 1997066. The author wishes to acknowledge constructive reviews of a previous version of the paper by Louise Corriveau and two anonymous referees, and a concise and helpful review by an anonymous journal reviewer.

\section{REFERENCES}

Aydin, N.S. 1995. Petrology of the composite mafic-felsic rocks of the Fogo Island batholith: A window to mafic magma chamber processes and the role of mantle in the petrogenesis of granitoid rocks. Ph.D. thesis, Memorial University of Newfoundland, St. John's, Newfoundland. 191 p.

Aydin, N.S., Malpas, J., \& Jenner, G. 1994. Physical characteristics of the Tilting Layered Suite, Fogo Island, Newfoundland. African Journal of Geology, 97, pp. 496-506

BAIRD, D.M. 1958. Fogo Island map-area, Newfoundland. Geological Survey of Canada. Memoir 301, 63 p.

BATCHElOR, R.A., \& Bowden, P. 1985. Petrogenetic interpretation of granitoid rock series using multicationic parameters. Chemical Geology, 48, pp. 43-55.

Brown, G.M. 1956. The layered ultramafic rocks of Rhum, Inner Hebrides. Philosophical Transactions of the Royal Society, A240, pp. 1-53.

CAwthorn, R.G. 1978. The petrology of the Tilting Harbour igneous complex, Fogo Island, Newfoundland. Canadian Journal of Earth Sciences, 16, pp. 526-539.

CURRIE, K.L. 1995. The northeast end of the Dunnage Zone in Newfoundland. Atlantic Geology, 31, pp. 25-38.

CURRIE, K.L. 1997a. A note on the geology of Change Islands, Newfoundland. Geological Survey of Canada Current Research, 1997-D, pp. 51-55.

CURrIE, K.L. 1997b. Geology of Fogo Island, Newfoundland - a study of form and emplacement of igneous intrusions. Geological Survey of Canada Current Research, 1997-D, pp. 45-54.

CURRIE, K.L. 1997c. Fogo map-area, Newfoundland. Geological Survey of Canada Open File 3466.

Currie, K.L., \& Pajari, G.E. 1981. Anatectic peraluminous granites from the Carmanville area, northeastern Newfoundland. Canadian Mineralogist, 19, pp. 147-161.

D’Lemos, R.S., \& Holdsworth, R.E. 1995. Samarium-neodymium isotope characteristics in the northeast Gander Zone. Geological Association of Canada Special Paper, 41, pp. 239-252.

Elliot, C.G., Dunning, G.R., \& Williams, P.F. 1991. New $\mathrm{U} / \mathrm{Pb}$ zircon age constraints on the timing of deformation in north central Newfoundland and implications for early Paleozoic Appalachian orogenesis. Geological Society of America Bulletin, 103, pp. 125-135.

GlazNer, A.F. 1994. Foundering of mafic plutons and density stratification of continental crust. Geology, 22, pp. 435-438.

Huppert, H.E., \& Sparks, R.S.J. 1988. The fluid dynamics of crustal melting by injection of basaltic sills. Transactions of the Royal Society of Edinburgh, Earth Sciences, 79, pp. 237-243.

Karlstrom, K.E., van der Pluijm, B.A., \& Williams, P.F. 1982. Structural interpretation of the eastern Notre Dame 
Bay area, Newfoundland. Regional post-Middle Silurian thrusting and asymmetrical folding. Canadian Journal of Earth Sciences, 19, pp. 2325-2341.

Kerr, A., Hayes, J.P., Colman-SAdd, S.P., Dickson, W.L., \& ButLer, J. 1993. An integrated lithogeochemical data base for the granitoid plutonic suites of Newfoundland. Unpublished contract report under the Canada-Newfoundland Mineral Development Agreement, 433 p.

Macdonald, G.A. 1963. Physical properties of erupting Hawaiian magmas. Bulletin of the Geological Society of America, 74, pp. 1071-1078.

Maniar, P.D., \& Piccoli, P.M. 1989. Tectonic discrimination of granitoids. Geological Society of America Bulletin, 101, pp. 635-643.

O'Brien, B.H., Swinden, H.S., Dunning, G.R., Williams, S.H., \& O'BRIEN, F.H.C. 1997. A peri- Gondwanan arc-back arc complex in Iapetus: early mid-Ordovician evolution of the Exploits Group, Newfoundland. American Journal of Science, 297, pp. 220-272.

Paterson, S.R., \& Vernon, R.H. 1995. Bursting the bubble of ballooning plutons: a return to nested diapirs emplaced by multiple processes. Geological Society of America Bulletin, 107, pp. 1356-1380.

Pearce, J.A., \& CANn, J.R. 1973. Tectonic setting of basic volcanic rocks determined using trace element analyses. Earth and Planetary Science Letters, 19, pp. 290-300.

Petford, N. 1996. Dykes and diapirs? Transactions of the Royal Society of Edinburgh, Earth Sciences, 87, pp. 105-114.

Piasecki, M.A.J. 1992. Tectonics across the Gander-Dunnage boundary in northeastern Newfoundland. Geological Survey of Canada Paper, 92-1E, pp. 259-268.

Sandeman, H.A., \& Malpas, J. 1995. Epizonal I and A-type granites and associated ash-flow tuffs, Fogo Island, northeast Newfoundland. Canadian Journal of Earth Sciences, 32, pp. 1832-1844.

Shervais, J.W. 1982. Ti-V plots and the petrogenesis of modern and ophiolitic lavas. Earth and Planetary Science Letters, 59, pp. 101-118.

Sylvester, A.G. 1964. The Precambrian rocks of the Telemark area in south-central Norway. III. Geology of the Vrådal granite. Norsk Geologiske Tidsskrifter, 44, pp. 445-482.
Tucker, R.D., Krogh, T.E., Ross, R.J., \& Williams, S.H. 1990. Time-scale calibration by high-precision U-Pb zircon dating of interstratified volcanic ashes in the Ordovician and Lower Silurian stratotypes of Britain. Earth and Planetary Science Letters, 100, pp. 51-58.

WaGer, L.R., \& BRown, G.M. 1968. Layered Igneous Rocks. Oliver and Boyd, London. 588 p.

WeInberg, R.F. 1996. Ascent mechanisms of felsic magmas. Transactions of the Royal Society of Edinburgh, Earth Sciences, 87, pp. 95-103.

Whalen, J.B., Currie, K.L., \& Chappell, B. W. 1987. A-type granites: geochemical characteristics, discrimination and petrogenesis. Contributions to Mineralogy and Petrology, 95, pp. 407-419.

WIEBE, R.A. 1994. Silicic magma chambers as traps for basaltic magmas: the Cadillac Mountain intrusive complex, Mount Desert Island, Maine. Journal of Geology, 102, pp. 423-437.

Williams, H. 1972. Stratigraphy of Botwood map-area, northeastern Newfoundland. Geological Survey of Canada Open File, 113, 98 p.

Williams, H., Currie, K.L., \& Piasecki, M.A.J. 1993. The Dog Bay Line, a Silurian terrane boundary in northeast Newfoundland. Canadian Journal of Earth Sciences, 29, pp. 2481-2494.

Williams, H., Dean, P.L., \& Pickering, K.T. 1995. Botwood Belt. In_Geology of the Appalachian-Caledonide Orogen in Canada. Edited by H. Williams. Geological Survey of Canada, Geology of Canada, 6, pp. 413-420.

Winchester, J.A., \& Floyd, P.A. 1977. Geochemical discrimination of different magma series and their differentiation products using immobile elements. Chemical Geology, 20, pp. 325-343.

Wood, D.A. 1980. The application of a Th-Hf-Ta diagram to problems of tectonomagmatic classification and to establishing the nature of crustal contamination of basaltic lavas of the British Tertiary volcanic province. Earth and Planetary Science Letters, 50, pp. 11-30.

Editorial responsibility: Sandra M. Barr 


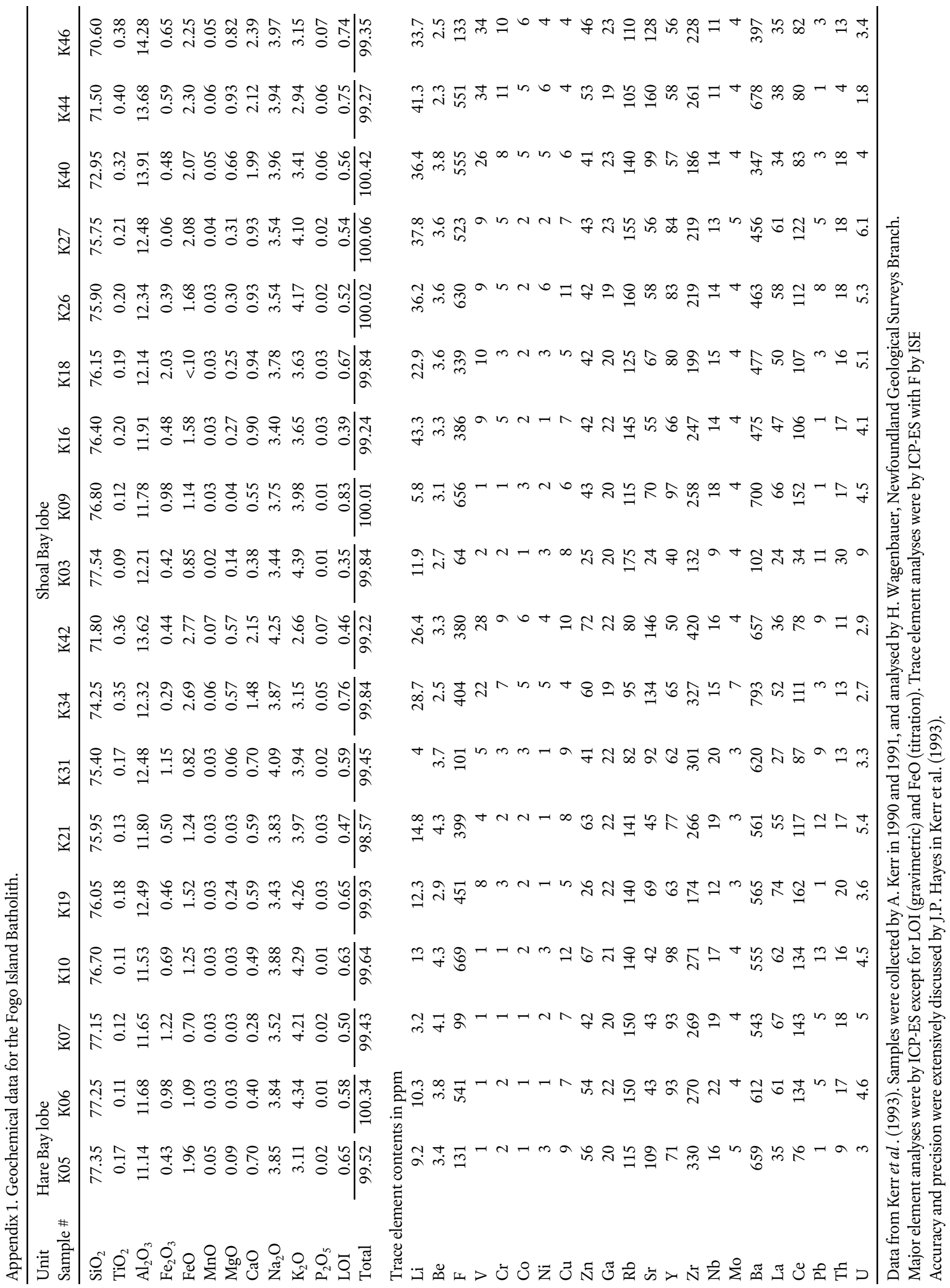




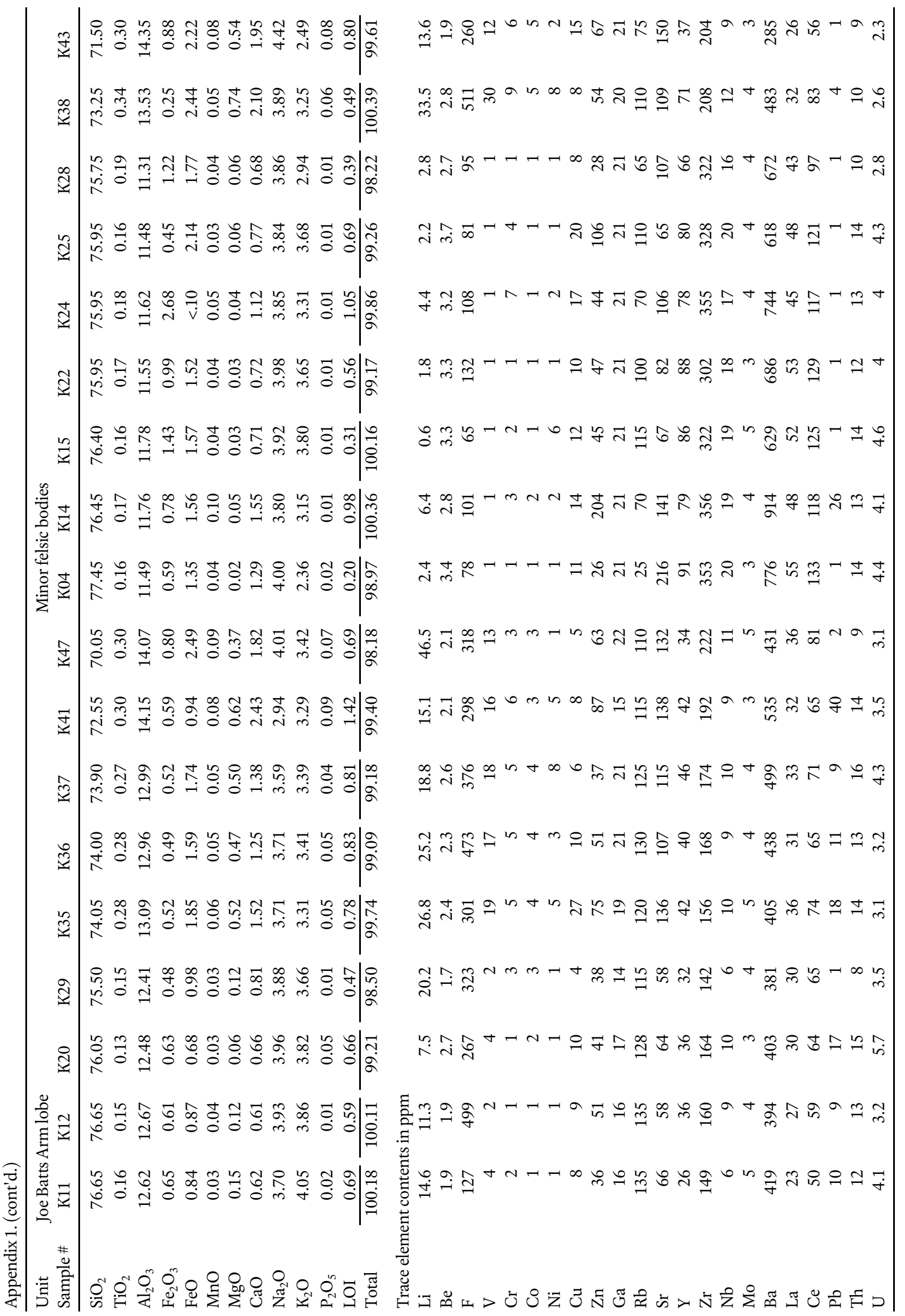




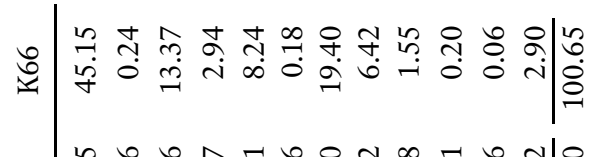

荤

구 융ㅇำ

ชి

สู

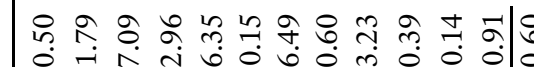

8 \&

串| 的

高

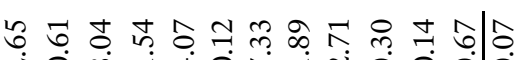

赵

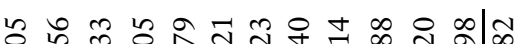

苟密

in 워의

他

选

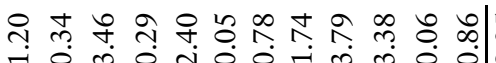

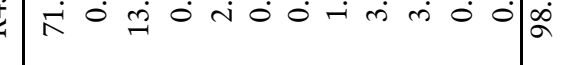

ڤ્વે

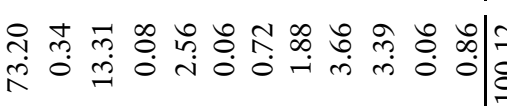

胥

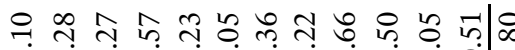

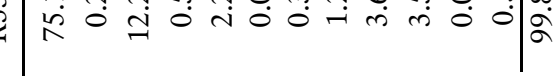

तึำ

ก ํำ

Е

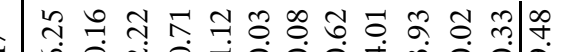

in n m 2 n n

胥

窟䞨

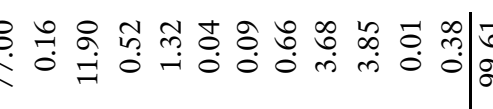

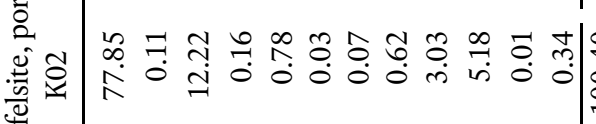

节 mூ

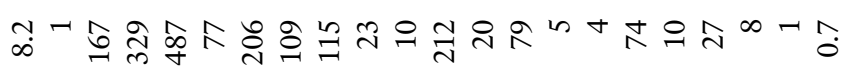

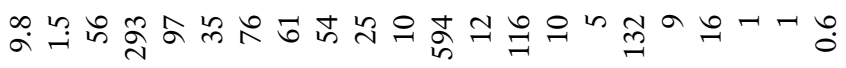

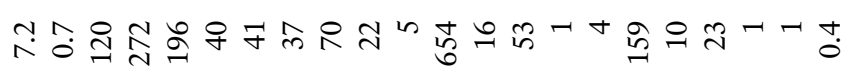

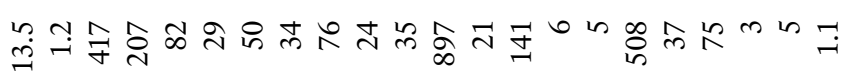

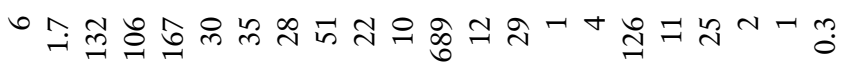

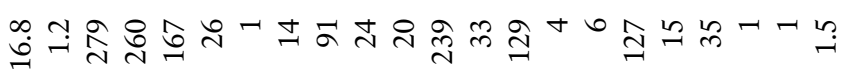

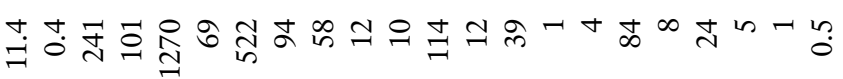

कृ

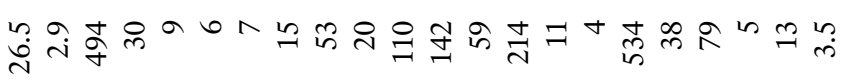

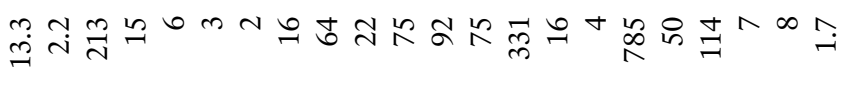

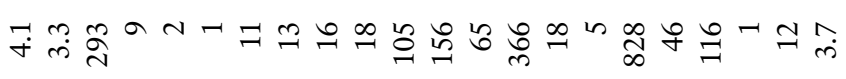

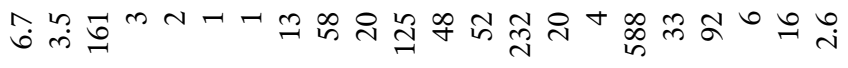

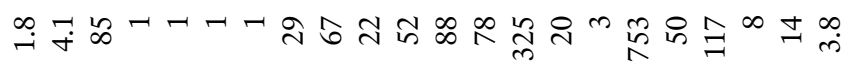

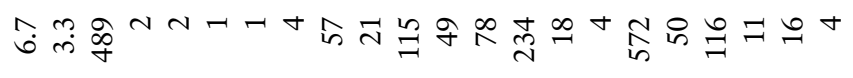

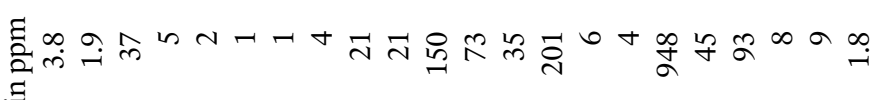
.

苞市

空

$\frac{2}{2}$

造

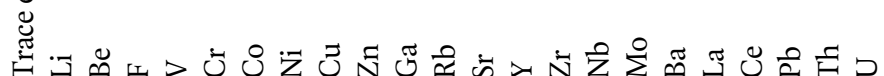




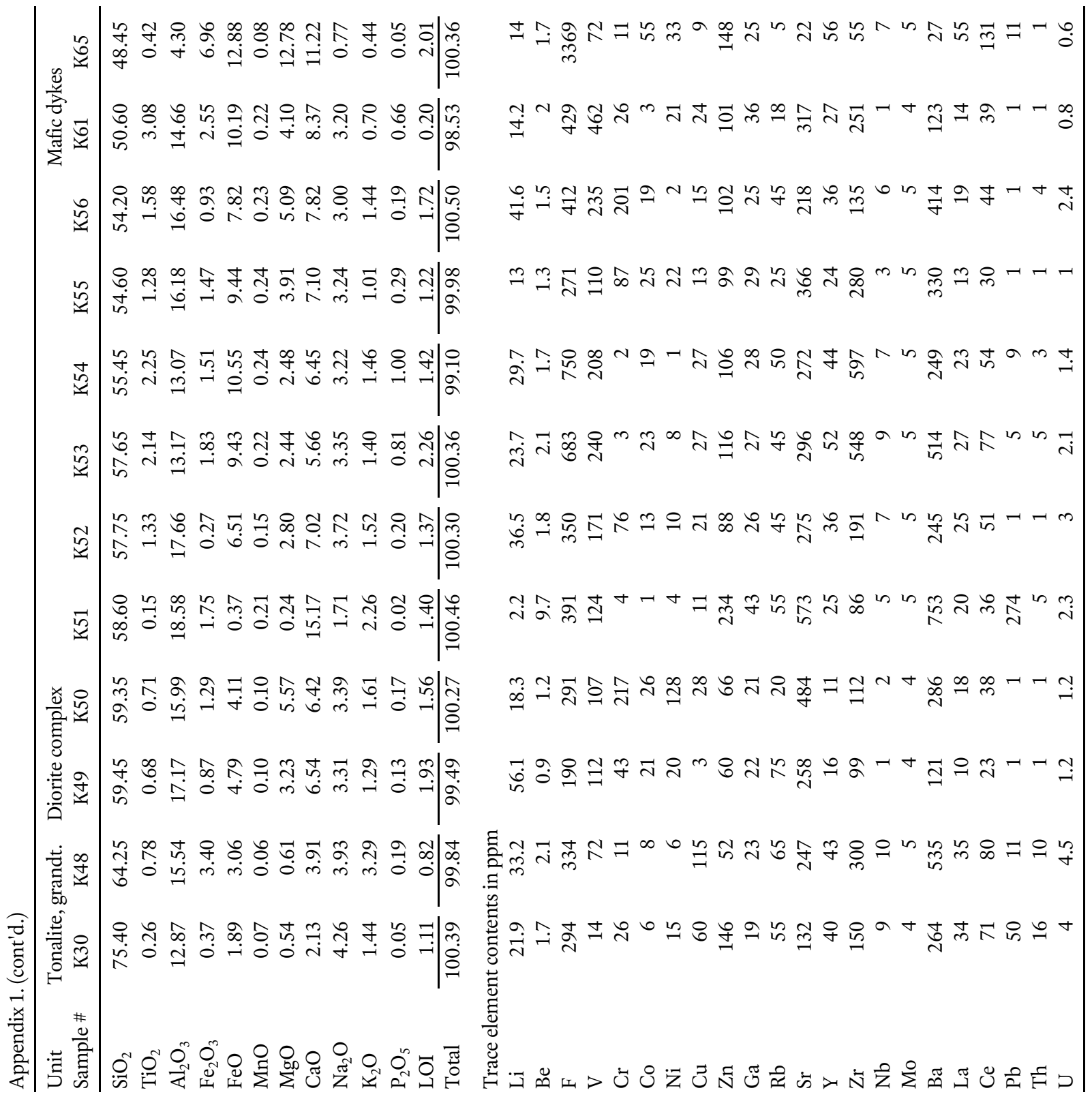




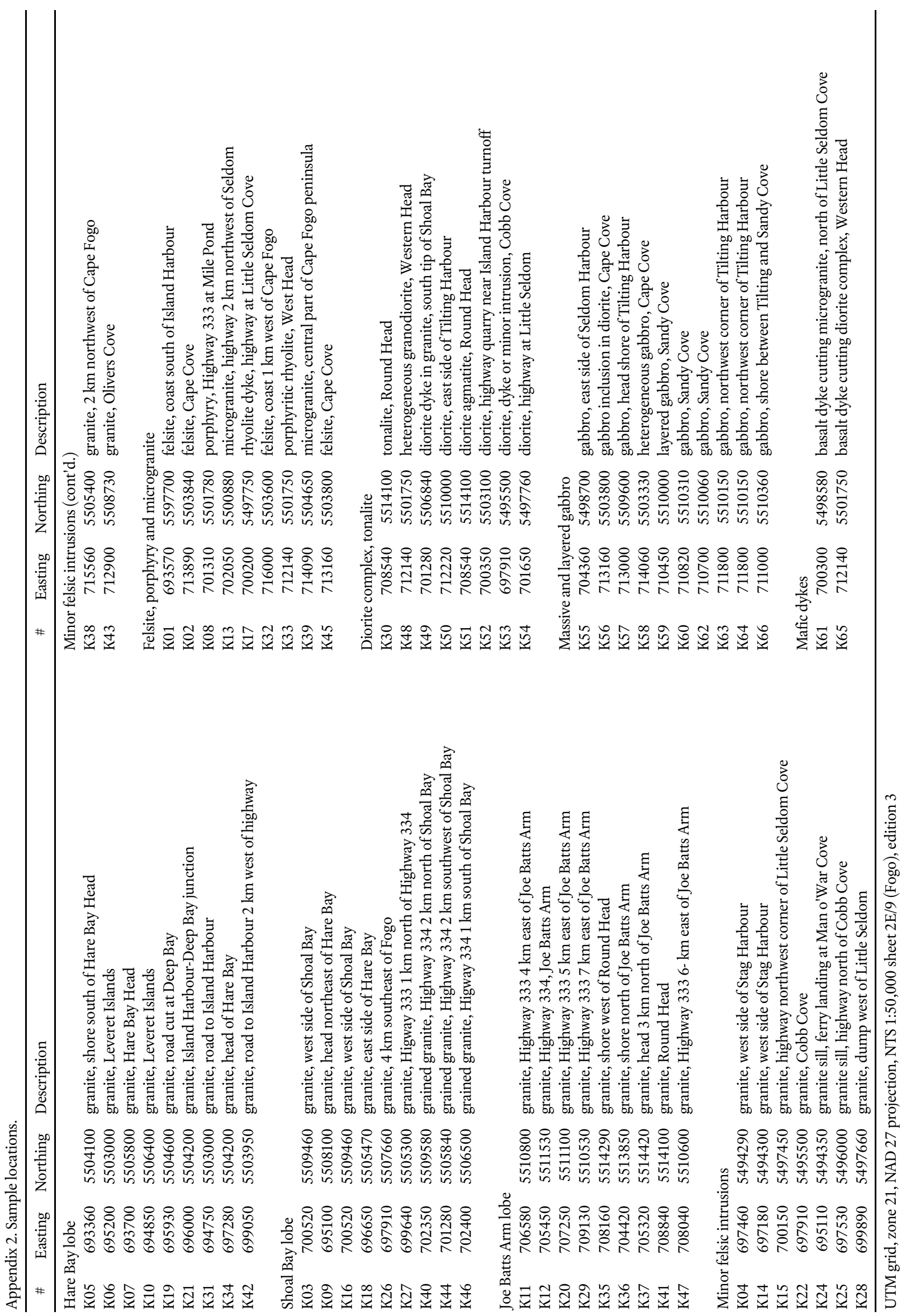

